\title{
MERCADERES Y ASOCIACIONES MERCANTILES EN EL COMERCIO TOLEDANO DE LA SEDA EN LA SEGUNDA MITAD DEL SIGLO XVII
}

por

\author{
HILARIO RODRÍGUEZ DE GRACIA
}

Universidad de Castilla-La Mancha

RESUMEN: A finales del siglo diecisiete, Toledo era uno de los principales centros de producción sedera, con un alto número de maestros, oficiales y aprendices. El sistema de venta de los productos manufacturados está en manos de los mercaderes. Comercializan la mayor parte de la producción, unas veces de forma individual y otras mediante sociedades. Algunos intervienen directamente en el proceso de fabricación y se denominan fabricantes. La mayor parte de ellos entregan a los tejedores un telar y la seda necesaria para confeccionar géneros tan variados como tafetanes, damasco, terciopelos o medias. Hay mercaderes que se encargan de traer la materia prima desde Murcia o Valencia, la cual pagan en monedas de plata y después entregan a los maestros sederos que trabajan adoptando una forma laboral denominada putting out system.

Algunos comerciantes son sólo inversores y establecen una compañía comercial con una persona que conoce bien el negocio, al cual se denomina factor. A partir de 1650 aumenta considerablemente su número, porque con esas sociedades se obtienen importantes ganancias. El análisis del número de socios, la duración, las ganancias conseguidas o el sistema de cobro que establecen son otras de las cuestiones que se tratan en este trabajo.

Palabras clave: Edad Moderna. Siglo XVII. España. Castilla. Toledo. Economía. Seda. Compañías comerciales. Mercaderes.

ABSTRACT: At the end of the seventeenth century, Toledo was one of the main centres of silk production. with a large number of masters, officials and appretices. Commercialisation was in the hans of the merchants. Most production was commercialised, either individually or through societies. Some of these merchants, the so-called manufacturers, intervened directly in the process of manufacturing. Most of them gave the weavers a loom and the silk that was necessary to make varied goods such as taffeta, damask, velvet or stockings.Some merchants were entrusted with bringing the raw material 
from Murcia or Valencia. This material was paid with silver coins. Later, merchants gave the raw material to silk masters, who adopted the practice known as the putting out system.

Some merchants were only investors; they established a commercial partnership with a person who knew the business well. This important profits might be obteined through those partnerships. In this paper, matters such as the analysis of number of members, the duration of their businesses, the profit obtained, and the system of collecting income are also explored.

KEY WORDS: Modern Age. Seventeenth century. Castile. Toledo. Economy. Silk. Commercial partnership. Merchants.

Dos funciones relacionadas con la actividad sedera toledana, la productiva y la mercantil, son los puntos esenciales que serán analizados en este artículo, en un marco temporal circunscrito a los últimos cincuenta años del siglo XVII, un periodo en el cual la crisis iniciada las primeras décadas de la centuria todavía hacía estragos en Toledo, aunque ya eran perceptibles cambios para superar regresión ${ }^{1}$. Ese periodo crítico produjo secuelas de cierta entidad y no fueron más intensas gracias a ser la cabeza de un extenso arzobispado, a tener un rico cabildo catedralicio y una nobleza de segunda fila, escasa, pero con cierta entidad consuntiva. Por el contrario, el artesano toledano, sobre todo el dedicado a la producción textil, perdía la pujanza que disfrutaba en años anteriores al no poder superar el amplio espectro de adversidades, y optó por abandonar su independencia o se trasladó a otro lugar ${ }^{2}$. No fue nada fácil sobrevivir con circunstancias tan adversas. Los que superaron la regresión lo hicieron gracias al amparo de un mercader, o porque se pusieron al servicio de una compañía comercial, urdiendo para ellos los encargo que le solicitaban. La proliferación de sociedades o compañías estuvo estrechamente ligada, por un lado, a la rentabilidad que los gestores obtenían y, en segundo lugar, porque los socios podían limitar su responsabilidad al valor del capital fundacional, en vez de responder íntegramente con su patrimonio.

\footnotetext{
1 La situación regresiva de principios del siglo XVII en VILAR BERROGAIN, Jean: «Un pessimisme "calcule"»: l'introspection économique à Tolède (1616-1628)», Toléde et l'expasion urbaine en Espagne. Madrid, 1991, pp. 117-135; y MARTínez GIL, Fernando: Toledo y la crisis de Castilla, 16771686. Toledo, 1987, pp. 35-41. Para segunda mitad de la centuria, Domínguez OrTiz, Antonio: Crisis y decadencia en la España de los Austrias «La crisis de Castilla en 1677-1687», Barcelona, 1973, pp. 197-217.

2 MONTEMAYOR, Julián: «Tolède en 1639», Melanges de la Casa de Velázquez, XVIII (1982), I, pp. 135-163, muestra dos elementos que considera son indicativos de la prosperidad. Primero, un $43 \%$ de la población del sector secundario se dedicaba a la actividades textiles; segundo, el comercio reunía al $30 \%$ de las ocupaciones del sector terciario.
} 


\section{EL PILAR ECONÓMICO DE LA SEDA}

Desde los primeros años del siglo XVII la ciudad comenzó a hacer frente a una crisis cuya coyuntura suscita todavía numerosas y dispares interpretaciones. De entre sus consecuencias más"directas debe entresacarse, por su excepcional importancia, la pérdida poblacional, ya que de los nueve mil vecinos que tenía Toledo en 1597 pasó a contar tan sólo con 4.889 vecinos en el año 1639. El mayor daño demográfico lo soportarían las parroquias obreras situadas en los suburbios, frente a las centrales que sobrellevaron la depresión con menor intensidad. Junto a la caída poblacional se desarrolló un inesperado retroceso económico, cuya incidencia no es posible valorar en su justa medida, aunque las consecuencias debieron ser profundas por conjuntarse con una fase profunda de encarecimiento y escasez de las subsistencias más básicas ${ }^{3}$. Las secuelas se hacían más extensivas debido a la degradación del vellón, ocurrida entre los años 1604 y 1627 , y el aumento de la presión tributaria acaecida en años posteriores ${ }^{4}$. La expulsión de los moriscos y el concurso de acreedores que afectó a los bienes municipales, sentenciado el año 1609, influyeron en el incremento de las contrariedades que soportaron los toledanos.

El ayuntamiento, con el embargo de los «propios», aceptó la intervención que impuso el Consejo de Castilla sobre la administración y gestión de los fondos municipales y renunció a ejercer la vigilancia que mantenía sobre los precios de los productos alimenticios más demandados, carne y trigo, cuyo servicio lo prestaba a través de las carnicerías y la alhóndiga. La trascendencia de esa dejadez se agudizó cuando los dos elementos reguladores antedichos entraban en un déficit tan acentuado que impedía pagar los préstamos censales. Para evitarlo se tomó la decisión de subir el porcentaje impositivo en los productos de mayor demanda 5 . El encarecimiento provocó secuelas irreversibles sobre el tejido productivo debido a que un alto número trabajadores del sector secundario salieron a instalarse en poblaciones cercanas, donde les resultaba más fácil obtener los productos básicos. Otros muchos se encaminaron a Madrid, una ciudad que experimentaba un continuo aumento poblacional y estaba necesi-

3 PÉrez Moreda, Vicente y ReHer, David: «La población urbana española entre los siglo XVI al XVIII", en FORTEA PÉreZ, J. Ignacio (ed.): Imágenes de la diversidad. El mundo urbano en la corona de Castilla (s. XVI-XVIII) .Santander, 1997, pp. 130-163. Las cifras de población proceden de MONTEMAYOR, Julián: Tolède entre fortune et declin (1530-1640). Limoges, 1996, pp. 147-157.

${ }^{4}$ La política inflacionista de los primeros años del reinado de Felipe III en SANTIAGO FerNÁNDEZ, Javier de: Política monetaria en Castilla durante el siglo XVII. Valladolid, 2000, pp. 62-73. SERRANO MANGAS, Fernando: Vellón y metales preciosos en la Corte del rey de España (1618-1668). Madrid, 1996, pp. 45-51.

5 GARCía SANZ, Angel: Desarrollo y crisis del antiguo Régimen en Castilla la Vieja. Economía y sociedad en tierras de Segovia, 1550-1844. Madrid, 1977, p. 218, evidencia las medidas adoptadas por otros concejos. 
tada de mano de obra, debido al aumento del consumo de múltiples productos, algunos suministrados hasta entonces por los talleres toledanos ${ }^{6}$.

Los efectos del declive poblacional tuvieron notable incidencia en el obraje de las sedas. No obstante, la actividad mantuvo su dinamismo como primera fuerza generadora de empleo y riqueza durante bastante tiempo después ${ }^{7}$. No menos importante sería la incidencia que produjo el retraimiento que experimentaban los intercambios mercantiles entre los años 1615 y 1625 , por la caída de las exportaciones sederas a Indias. El causante hay que buscarlo en la introducción de telas procedentes de China a través de los puertos indianos del Pacífico, convertidas en un artículo de gran aceptación en los virreinatos indianos al ser más baratas que las fabricadas en España, que soportaron unos costes de producción más altos ${ }^{8}$.

Las posibilidades para orientar la situación serían limitadas y hasta se constriñeron cuando el ambiente de crisis generó el aumento de las obligaciones impagadas a su vencimiento. El fuerte retraimiento en la dinámica comercial hizo que muchas deudas fuesen incobrables y redujesen, a un amplio grupo de comerciantes, las posibilidades de contar con fondos para efectuar nuevas compras. Aquella inestabilidad sería aprovechada por capitalistas y mercaderes para trasladar gran parte de los capitales comerciales a inversiones más seguras, mientras que otros cuantos liquidaban sus negocios temporalmente. Los síntomas de crisis tuvieron que afectar con dureza, y de forma preferente, a la ya decaída industria lanera, cuyo momento más depresivo comenzó en la década final del siglo XVI y llevó a la casi desaparición de la confección de aquellos tejidos, lo que permitió aumentar los envíos de lanas a Flandes y Génova, des-

6 ARChivo MUNiCIPAL DE TOledo (AMT), Seda, legajo 1, «Sobre que no hubiera telares fuera de Toledo y los maestros que había en Madrid se viniesen a Toledo», años 1619. Alvar EzQuERRA, Alfredo: El nacimiento de una capital europea. Madrid entre 1561 y 1606. Madrid, 1989, p. 215 muestra los retoques urbanísticos. RINGROSE, David: «Madrid, capital imperial, 1561-1833», Madrid. Historia de una capital. Madrid, 1995, pp. 189-198, consideró que el aislamiento del interior de Castilla tuvo consecuencias sobre la vertiente comercial a gran distancia. Una visión de la crisis en los artículos del volumen editado por THOMPSON, I.A.A. y YUN CASALILLA, Bartolomé (eds.); The Castilian crisis of the seventeen century. Cambridge, 1994.

7 MARTZ, Linda y PORRES MARTíN-CleTO, Julio: Toledo y los toledanos en 1561. Toledo, 1975, gráficos 1 y 2. MONTEMAYOR, Tolède... pp. 162-167, incluyen curvas de mortalidad y natalidad de doce parroquias, como hizo con anterioridad WEISSER, Michel: «The decline of Castile revisited. The case of Toledo", Journal of European Economic History, vol. III (1973), pp. 614-640/622. En ambos trabajos citados, conviene advertir, no aparecen los valores numéricos con los que los autores trabajan, lo que hace dificultosa cualquier revisión de sus estimaciones estadísticas.

8 RINGROSE, David: «El desarrollo urbano y la decadencia española», Revista de Historia Económica, año 1, núm 1 (1983), pp. 37-57, en especial p. 49, afirma que los mercados extranjeros se perdieron a consecuencia de los altos coste de producción. Los memoriales en RODRíGUEZ DE GRACIA, Hilario: El crepúsculo patrimonial de Toledo, Toledo, 1999, pp. 179-185. OlIVARES GALVÁN, Pedro: El cultivo y la industria de la seda en Murcia (siglo XVIII). Murcia, 1975, pp. 27, 203-5, cita la prohibición de sedas procedentes de China, India y Persia para evitar la competencia..

Hispania, LXII/1, núm. 210 (2002) 65-112 
de donde se reexpedían telas confeccionadas 9 . A la hora de pergeñar las secuelas de momentos tan inestables, una de la más visible fue el incrementó del número de quiebras y suspensiones de pago entre los mercaderes genoveses y castellanos establecidos en la ciudad, tanto para los que comerciaban con lanas como para quienes lo hacían con seda ${ }^{10}$.

Del declive de los primeros años del siglo XVII se conservan citas bastante creíbles que fueron elaboradas por un amplio espectro de instituciones, académicas, religiosas, civiles y personas a título individual. En jugosas páginas manuscritas o impresas, los llamados arbitrios, quedaron patentes lo que, a su entender, originaba el hundimiento de una ciudad tan boyante. A la par, los autores de los escritos aconsejaban soluciones para lograr la recuperación con la intervención de rey. La respuesta nunca tuvo el efecto deseado, al estar la Corona inmersa entonces en problemas de mayor envergadura que los lamentos de los toledanos. En su mayoría, los arbitrios describieron una ciudad desolada, con numerosos recursos productivos abandonados, casas en ruina y un descenso considerable de operarios. Sin embargo, la realidad crematística no debió ser tan dramática. De ser como la pintan los arbitristas resultaría inexplicable que con posterioridad Toledo mantuviera intacto su carácter urbano. A pesar del declive demográfico que sufrió y enfrentarse a una coyuntura adversa de desmedida intensidad, cuya prolongación duró hasta avanzado el siglo XVIII, conservó casi intactas, durante bastante tiempo, las estructuras ciudadanas.

Algunos sectores sufrieron más que otros las secuelas. En este sentido, el gremio de la seda padeció a partir de los primeros años de setecientos una parálisis considerable, que se agudizaban, debido a la falta de numerario, entre 1649 a 1652, a la cual se conjuntaba la insuficiente oferta de plata que en años posteriores constriñó las actividades sederas. Aquel coadyuvante tuvo bastante repercusión en el mundo comercial, muy en especial cuando los mercaderes se vieron obligados a pagar sus compras de materia prima en plata. El aumento de la demanda y la escasez de metales provocaban que los índices de conversión subieran hasta convertirse en una operación gravosa para los mercaderes que entregaban vellón para adquirir plata. El cambio implicó un premio o interés, mayor en función de la escasez de la plata, cuyo encarecimiento revirtió sobre el precio de la seda en hilo y tramada que consumían los telares. Por otro lado, y de no menos importancia en toda la dinámica descrita, al aumentar los costes de la materia prima se produjo una caída en la tasa de beneficios, lo que desanimó a quienes tenían posibilidades económicas de invertir en el sector co-

9 Con anterioridad, concretamente en 1619, Juan Belluga de Moncada, agente general de Toledo en la Corte, aconsejó pleitear para anular la implantación del oficio de veedor de los paños. Advertía que los géneros se fabricaban en Segovia y Cuenca, pero que la producción en Toledo era escasa, al no «haber en esta ciudad telares ni fábricas de paños». AMT. Cartas, 1648. Informe de Andrés Vaillo.

10 Toledo presentó el año 1617 el mayor número de quejas, de lo cual da testimonio DomínGUEZ OrTIZ, Antonio: La sociedad española en el siglo XVII. Madrid, 1963, t. I, pp. 138-9. 
- mercial, porque sus previsibles ganancias eran inferiores al tipo de interés vigente. También tuvo incidencia sobre la industria toledana la entrada de tejidos extranjeros que se vendían, sin demasiadas trabas; por las ferias castellanas, a pesar de la pragmática proteccionista promulgada el año 1623, que no cumplió el objetivo de restringir las importaciones. En las primeras décadas del siglo XVII, los tejidos de seda perdieron competitividad frente a los géneros que llegaban de China, ciertamente de una calidad inferior aunque atrayentes para el bolsillo de los consumidores. Esa competencia en calidad, por un lado, y calidad-precio, por otro, limitaban las expectativas para intervenir en el mundo comercial. Aun así hubo mercaderes que aprovecharon la coyuntura de los años ochenta para arañar beneficios con el comercio de los géneros de seda, a veces, si se prefiere, con la aplicación de métodos un tanto cicateros, donde el objetivo de calidad quedó un poco arrinconado ${ }^{11}$. Aquellos que se nombraban fabricantes aprovecharon de forma más eficiente las sinergias que les ofrecía el mercado, mientras los intermediarios entre el artesano y el consumidor, los mercaderes de menor enjundia, que fueron escrupulosos en el proceso de fabricación, conseguirían unas ganancias modestas y poco significativas.

Los que eran fabricantes mantuvieron la siguiente línea de actuación. Directamente compraron la seda en las zonas productoras, la traían a la ciudad, se la daban para transformar a sus maestras y vendían los tejidos en puntos muy alejados del lugar de fabricación, donde los vaivenes de la competencia eran menos perceptibles. Al proceso de confección aplicaron un método de producción que consistía en hacer los tejidos a un coste más bajo que los de la competencia, en ese caso los maestros tejedores independientes. Para lograr ese objetivo, dicho de otro modo, tuvieron que introducir procedimientos irregulares. Uno de ellos consistió en adulterar las materias primas con mixturas de peor categoría; otro, ante la abundancia de telares sin trabajo, consistió en ajustar el precio de la confección por debajo del valor que fijaba el gremio. Aunque es menos evidente también llegaron a eludir, con múltiples mañas, los impuestos de tránsito de la seda en hilo, la que llegaba sin teñir desde Valencia, en detrimento de la seda murciana que hasta entonces gozaba de una relativa propensión.

Hacia la mitad de siglo comenzaban a ser patentes signos más propicios para el sector ${ }^{12}$. El cambio a una situación más bonancible queda patentizada en los ingresos de la correduría de la seda. Desde la década de los años cuarenta

${ }^{11}$ En AHMT. Caja 2.291 hay una amplia variedad de órdenes reales sobre la industria y comercialización de los tejidos sederos

12 Ringrose, David: «The impact of a New Capital City: Madrid, Toledo and New Castile, 1560-1660" Journal of Economic History, 33 (1973), pp. 761-791, opina que entre 1595-1630 la situación económica no pudo apuntalarse por dos circunstancias: el fuerte crecimiento de Madrid y las sucesivas crisis de subsistencia que sufrió Toledo. Los intentos de restablecer la industria sedera desde altas instancias, en los años 1683 y 1698, en GARZÓN PAREJA, Manuel: La industria sedera en España. El arte de la seda en Granada. Granada, 1972, pp. 79-82; y GARCíA RUIPÉREZ, Mariano: La Real Compañía de Comercio de Toledo, Toledo, 1986; p. 39 
venían bajando, pero al llegar los cincuenta se estabilizaban y así permanecían hasta 1660. En la década siguiente crecieron un poco, lo cual permite atisbar, por ello mismo, una recuperación que se prolongó hasta los años ochenta, aunque tuvieron que enfrentarse a la competencia de los géneros que introducían los mercaderes genoveses establecidos en Madrid. Aquel movimiento facilitó la expansión de diversas sinergias, que se hicieron extensibles en otros sectores manufactureros, hasta el punto que la ciudad parecía recuperaba, si no en su totalidad, parcialmente, el carácter económico que disfrutó con anterioridad ${ }^{13}$. Es casi seguro que el origen de ese cambio haya que buscarlo en una coyuntura agrícola alcista ${ }^{14}$. Los ingresos que obtuvo la Obra y Fábrica en concepto de diezmos son uno de los elementos apropiados para marcar la línea de evolución, cuya cota más alta, a tenor de los datos contenidos en el cuadro I, se situó entre 1649-52 y la menor entre 1683-85.

CUADRO I. Ingresos catedralicios por partidos eclesiásticos (en mrs.)

\begin{tabular}{|c|c|c|c|c|c|c|c|}
\hline AÑO & TOLEDO & LA GUARDIA & ILLESCAS & TALAVERA & C. REAL & ALCALÁ & GUADALAJARA \\
\hline 1603 & 295.711 & 784.604 & 588.666 & 439.358 & 1.066 .068 & 580.788 & 891.545 \\
\hline 1604 & 209.326 & 392.602 & 723.573 & 353.105 & 1.057 .783 & 762.395 & 1.169 .861 \\
\hline 1606 & 236.054 & 416.55 & 888.792 & 395.163 & 1.145 .249 & 1.151 .257 & 1.306 .528 \\
\hline
\end{tabular}

\begin{tabular}{|l|l|l|l|r|r|r|l|}
\hline 1648 & 303.818 & 972.922 & 1.268 .783 & 627.348 & 1.225 .979 & 1.017 .784 & 1.873 .061 \\
\hline 1649 & 275.732 & 976.824 & 1.239 .227 & 575.301 & 990.051 & 912.937 & 1.761 .455 \\
\hline 1650 & 300.536 & 906.793 & 1.330 .793 & 692.319 & 1.014 .266 & 1.161 .580 & 2.255 .326 \\
\hline 1651 & 325.763 & 690.772 & 1.170 .823 & 890.131 & 1.508 .409 & 1.330 .579 & 2.523 .470 \\
\hline 1652 & 296.642 & 914.983 & 1.129 .351 & 687.876 & 1.456 .850 & 1.183 .585 & 2.092 .320 \\
\hline
\end{tabular}

\begin{tabular}{|l|l|l|r|r|r|r|r|}
\hline 1681 & 220.383 & 821.920 & 424.432 & 384.576 & 410.102 & 1.007 .743 & 675.318 \\
\hline 1683 & 170.647 & 248.201 & 458.290 & 297.622 & 177.030 & 756.524 & 1.442 .373 \\
\hline 1684 & 213.297 & 357.126 & 542.598 & 483.638 & 247.341 & 1.018 .005 & 1.665 .087 \\
\hline 1685 & 207.753 & 282.158 & 399.590 & 298.657 & 253.266 & 696.421 & 1.521 .428 \\
\hline 1686 & 143.001 & 497.291 & 412.376 & 644.152 & 288.564 & 759.546 & 1.364 .177 \\
\hline
\end{tabular}

Fuente: ACT. Libros de frutos y gastos

13 LARRUGA Y BONETA, Eugenio: Memorias políticas y económicas sobre los frutos, comercio, fabricas y manufacturas de España. Madrid, 1790, t. VII, pp. 208-210.

${ }^{14}$ LÓPEZ SALAZAR, Jerónimo y MARTíN GALÁN, Manuel: «La producción cerealística en el arzobispado de Toledo, 1463-1699», Cuadernos de Historia Moderna y Contemporánea 2 (1981), pp. 21-103, anotan que los rendimientos pasan del índice 53,5, en 1500-09, al índice 91,2 en 1530-9. Ese ritmo fue muy difícil de mantener en décadas posteriores y provocó un desajuste entre el aumento demográfico y la producción agrícola. 
El aumento de las rentas decimales, a consecuencia de mejores cosechas, actuó de impulsor en la actividad constructora. Numerosas iglesias del arzobispado fueron reparadas al contar las fábricas con mayores ingresos; otras eran ampliadas, se adornaban los altares con nuevos retablos, tallas y eran colocadas pinturas para embellecer las paredes de capillas y oratorios. La onda expansiva de la reactivación económica se propagó por otros sectores artesanales. La recuperación permitió que Toledo restableciera, momentáneamente, su condición de polo de atracción artística, lo cual se tradujo en la llegada, para hacer trazas y diseños, de reputados arquitectos, escultores y pintores, entre los que cabe citar, olvidando a otros más secundarios, a Lupercio de Falces, José Machín, Juan de Mora, Juan Gómez Lobo, Pedro García Comendador, Juan García de Sampedro, Juan Muñoz de Villegas, Hipólito Torres, Juan Pablo de Estrada, Rizzi o Caxés ${ }^{15}$.

En el plano económico, los efectos de ese circunstancial despegue se constataban en el sector protoindustrial y mercantil. La repercusión más visible fue el restablecimiento de la antigua condición de centro neurálgico entre Castilla y Andalucía, de conexiones comerciales muy fluidas con anterioridad y bastante decaídas posteriormente. Ello explicaría también, cómo sin llegar a las cotas alcanzadas en el siglo XVI, Toledo volvió a recuperar su condición de enlace de flujos económicos entre el interior peninsular y los puertos de Valencia y Cartagena ${ }^{16}$. Por otro lado, no debe olvidarse la posibilidad que ofreció a la economía ciudadana en ese momentáneo despegue la permanencia de Mariana de Austria en la ciudad, aunque fuese en el dorado exilio del Alcázar, soterrada prisión con aíres de corte, que incrementaba los consumos diarios y la demanda de artículos variopintos. Es una etapa excesivamente corta, pero no desaprovechada por comerciantes y artesanos.

La fase del ciclo económico alcista se ralentizó en la segunda mitad del siglo por culpa del incremento fiscal. Las autoridades municipales ampliaron el número de arbitrios ante los requerimientos económicos de la Corona, los llamados donativos, cuyo destino serían las guerras surgidas entre la monarquía hispana y Luis XIV. Toledo acopió las cifras exigidas a través de préstamos efectuados por particulares, censos redimibles, cuyo pago realizó percibiendo un arancel de un amplio espectro de productos que entraba intramuros. Tal sobrecarga fiscal imposibilitó romper los condicionantes de la recesión y, al contrario, la prolongó porque los ingresos de la exacción eran inferiores que los réditos percibidos por los particulares tenedores de los $\operatorname{censos}^{17}$.

15 Una visión general en SUÁREZ QUEVEDO, Diego; Arquitectura barroca en Toledo. Siglo XVII. Toledo, 1990, pp. 26-27.

16 VelasCo HernáNDEZ, Francisco; «Capitalismo y burguesía mercantil. El puerto de Cartagena en el periodo de 1560 a 1630», Contrastes, Revista de Historia Moderna, núm 5-6 (1989-90), pp. 21-35, resalta el negocio de las lanas como una de las actividades sobresalientes, consignadas desde Cartagena a Italia

17 MarTínez GiL, Toledo y la crisis..., pp. 162-3 cree que entre 1683-1699 se produjo una recuperación momentánea. Sería conveniente ratificar con datos más precisos la evolución coyuntural de la economía toledana en la segunda mitad de la centuria.

Hispania, LXII/1, núm. 210 (2002) 65-112 


\section{UN MONOPOLIO SEDERO FRACASADO}

En los primeros años del Seiscientos varios personajes prestigiosos de la vida pública elaboraron arbitrios con el fin de detener la ruina que se cernía sobre Toledo. Entre ellos cabe destacar a Alonso de Castro Xibaje, Damián de Olivares, Jerónimo de Ceballos, García de Herrera, Pedro de Alcocer o Sancho de Moncada $^{18}$. Del selecto elenco mencionado, Moncada será el más interesado en proponer actuaciones encaminadas a la reactivación económica, de cuyo pensamiento dejó constancia en varios arbitrios, algunos todavía inéditos. Uno de éstos llama la atención, aún repitiendo las indelebles ideas mercantilistas que caracterizan su pensamiento, al descansar su corolario en el crecimiento del cultivo de.la seda, algo que en la ciudad escaseaba y debía traerse de lugares bastante alejados. Para conseguir su propósito recomendaba la ampliación de la superficie destinada a las moreras. Las nuevas plantaciones de árboles, escribió, debían ponerse en terrenos destinados a pastizales y en los cigarrales - parcelas de un policultivo de subsistencia - que se hallaban repartidos por los montículos cercanos a la ciudad. Aquellas tierras, de escasa utilidad como tierras de labor, serán en la teoría de Moncada las adecuadas para la plantación de las morus alba, un árbol de hojas muy refinadas, que resultaban exquisitas como alimento para las larvas anélidas ${ }^{19}$. La abundancia de moreras, formulaba el arbitrista, facilitaría la crianza de gusanos y convertiría a la ciudad en un eje monopolista de la seda en bruto, recuperando su condición de foco de intercambios en productos elaborados, a la par que se liberaría de la dependencia que tenía con suministros externos. Desde el punto de vista crematístico, la industria sedera obtendría, en su condición de insumo incorporado al proceso de producción, un valor añadido cuantioso al ser la materia prima abundante en el mismo lugar donde se confeccionaban los tejidos. Por esas dos circunstancias, la ciudad podría establecer un monopolio de criadores de seda y actuar éstos como proveedores exclusivos de sus artificios, además de vender el excedente a los telares situados en poblaciones cercanas y suministrar también a los establecidos de otras zonas peninsulares.

Cuando Moncada escribió este arbitrio, la industria sedera toledana se enfrentaba a una serie de impedimentos muy coactivos, como eran una alta fiscalidad y una excesiva competencia que producían enormes perjuicios a los teje-

${ }^{18}$ Numerosas aportaciones doctrinales en ARANDA, F. José: «La preocupación "arbitrista" en el seno del ayuntamiento de Toledo: por la declinación de la ciudad en un periodo crítico, 16181621 », Toletvm 29 (1993), pp. 201-227. SANTOS VAQUERO, Ángel: «Memorial del mercader toledano Damián de Olivares, del 17 de febrero de 1626», Espacio, Tiempo y Forma, núm 12, serie IV (1999), pp. 151-180. Un análisis general en PERDICES DE BLAS, Luis: La economía política de la decadencia de Castilla en el siglo XVII: investigaciones de los arbitristas sobre la naturaleza y causas de la riqueza de las naciones. Madrid, 1996.

19 CARANDE, Ramón: Carlos V y sus banqueros. Madrid, 1990, pp. 198, analiza la innovación alimenticia de los gusanos y la crisis de la industria de la sedería valenciana en la mitad del siglo XVI.

Hispania, LXII/1, núm. 210 (2002) 65-112 
dores y a otras industrias auxiliares. Algunas de las pinceladas más sombrías y conminatorias para el sector quedaron reflejadas en las continuas quejas que las corporaciones gremiales enviaron a los procuradores en las Cortes. Con ellas buscaban soluciones y su consecución, con cierto éxito, instaron a los diputados en las Cortes, muy en especial las convocadas el año 1607, para que demandasen al rey algunas exenciones fiscales, tanto para la materia en bruto que llegaba a la ciudad, para la mercancía que se vendía fuera de ella, como para las técnicas que empleaban los dos artes sederos se acoplasen a las variaciones que experimentaba la demanda ${ }^{20}$.

Es de lamentar que las ideas moncadianas no tuvieran una plasmación inmediata y la dilación hay que achacarla al escaso interés que demostraron los propietarios de los terrenos donde debían establecerse los cultivos, al.considerar que les resultaba más rentable dedicarlos a criar hortalizas, frutales y olivos, en vez de moreras. La plantación de los árboles requería una inversión costosa, de beneficios a largo plazo, frente a la inmediatez de los ingresos, aunque escasos, que proporcionaban los cultivos tradicionales, mucho más cuando la propiedad donde debían efectuarse los plantíos era de conventos e instituciones religiosas, que tenían entregada la explotación a arrendatarios ${ }^{21}$ Con el paso de los años, el plan de extender las plantaciones de moreras no era tan insubstancial que quedaba olvidado. El proyecto, por el contrario, sería reactivado el año 1708 gracias a nuevas iniciativas privadas y colectivas, cuyo objetivo ahora estaba centrado en recuperar la actividad sedera. Consiguieron una Real Cédula para ello, en la cual se aconsejaba la plantación de morales en legua y media del contorno urbano, un espacio comprendido entre los molinos de Higares y la confluencia del Guadarrama ${ }^{22}$.

\section{DISMINUCIÓN DEL NÚMERO DE TELARES}

En función del número de artificios que poseyó la sedería toledana, el ilustrado Eugenio Larruga diferenció varias etapas para situar la evolución y su desarrollo. A la hora de fundamentar sus conclusiones creyó que los problemas estructurales surgidos con anterioridad a 1600 no fueron graves para el arte mayor, ni tuvieron excesiva incidencia sobre el menor de la seda; de ahí la escasa variación en el número de telares que trabajaba dentro de la ciudad. En la

${ }^{20}$ El testimonio procede de AHPT Protocolos, 3087, fol. 452 y 675, año 1621, escribano Rodrigo de Hoz. CEBRIÁN REY, Alfonso: «Una visión de la crisis de la industria sedera toledana en el primer tercio del siglo XVII: el memorial de Juan González de Vatres Sotomayor», Espacio, Tiempo y Forma, 11 (1998), pp. 239-264, analiza la crisis de la sederías toledanas.

21 RODRígueZ DE GrACIA, Hilario: «De la huerta del Rey a la Alberquilla», Anales Toledanos, XIX (1984), pp. 39-68.

22 AHMT. Seda, caja 2291, Ordenanzas, 1500-1650, alegaciones a la pragmática de 1675. Cada fanega de tierra podían contener ochenta árboles. 
primera mitad del siglo XVII todavía se mantuvo la prosperidad, aún soportando contrariedades, para cambiar el panorama a una situación regresiva durante la otra mitad de la centuria. En aquel contexto, las opiniones de Larruga son difíciles de matizar actualmente, aunque es casi cierto que el ciclo bonancible, aún sorteando trastornos eventuales, pudo mantenerse sin excesivas alteraciones hasta 1663. En los años anteriores a 1645, según sus cálculos, el total de artificios superaba los diez mil, aunque al llegar 1651 dejaban de funcionar cerca de dos mil. La cifra no es desdeñable y la caída representa la pérdida de la mayor fuerza generadora de empleo para una ciudad que contaba con una población, en números redondo, de cinco mil vecinos ${ }^{23}$. Sería correcto, en consecuencia con la opinión y las cifras aportadas, sostener que la industria sedera fue en aquel entonces un input muy dinámico, de transcendental importancia, cuya categoría fue debilitándose a partir de la segunda mitad de la centuria. Un cambio de tendencia, que debió producirse, por dar una fecha aproximada, a finales de la década de los sesenta, hizo que el número de telares se situase en 7.365 artificios; casi dos mil setecientos menos que en la medición anterior. La situación decadente se prolongaba hasta los años ochenta, cuando volvían a perderse otros mil cuatrocientos telares más. A partir de entonces, quizá entre 1683-84, comenzó a vislumbrarse una tendencia de recuperación, de corta duración y lenta reacción, que es más visible el año 1685, ya que en 1691 comenzó a sentirse otra fase de decrecimiento. Esta vez, la causa del retroceso la propició la exigüidad de seda que venía desde Valencia, lo que hizo encarecer su precio e imposibilitó que fuese accesible a los maestros no vinculados a un mercader ${ }^{24}$.

¿Tuvo el descenso el significado de señal de alarma? ¿Es un signo evidente para asegurar que el sector sedero atravesaba un momento crítico? ${ }^{25}$. Son dos preguntas a las cuales no es fácil dar una respuesta inmediata. Lo que resulta verosímil es que la reducción en el número de telares hasta sólo 5.600 unidades fue un proceso de una larga evolución y, como mínimo, duró hasta la década de los años ochenta. Larruga aduce que, en 1685, los dedicados a tejer géneros

23 LARRUGA: Memorias políticas..., t. VII, pp. 207 evalúa el número en 9.561 unidades. Dos informaciones sobre telares contienen los datos siguientes. En una, del año 1692, se contabilizan 285 artificios para tejer terciopelos, felpas, damascos, raso, sargas, gorgoranes, etc. La otra se hizo el año 1693 y aparecen 622 artificios de rizo, fondo, terciopelo, felpas, rasos y mantos. Es muy extraño que los telares de listonería, los llamados de menor, no aparezcan reflejados, porqué sumaban algunos cientos. MONTEMAYOR, «La seda en Toledo en la época moderna», España y Portugal en las rutas de la seda, Madrid, 1996, p. 123.

${ }^{24}$ Las cifras de distribución parroquial de los telares en MARTín GAMERO, Antonio ; Los cigarrales de Toledo. Toledo, 1857, p. 155. MOTA, Almudena de la: Tejidos artísticos de Toledo. Toledo, 1980 , p. 37.

${ }^{25}$ LARRUGA: Memorias políticas..., t. VII, pp. 210 incluye la petición de Medrano para establecer artificios y sus exigencias. Para CASEY, James: El reino de Valencia en el siglo XVII, Madrid, 1983, p. 92, las manufacturas sederas valencianas resurgieron hacia 1670. El volumen máximo de exportaciones a Castilla se alcanzaba en 1686, con un declive a partir de 1699. Esa evolución queda reflejada en los ingresos arancelarios toledanos.

Hispania, LXII/1, núm. 210 (2002) 65-112 
de ancho aumentaron en un millar, mientras los de listonería se situaban en cuatros millares. En los cuatro años posteriores se perdían 470 telares de ancho y 2.000 de listonería, eso quiere decir que produjo una reducción en las compras de materias textiles, disminuyó el valor de la producción final, limitó la de otros bienes, afectó a la actividad comercial y, sobre todo, aumentó el paro entre los artesanos, obligándoles a emigrar y a sobrellevar múltiples adversidades ${ }^{26}$.

La información de Larruga sobre la pérdida de telares se puede complementar con otra, ésta menos empírica, como es una información conservada en el Archivo Municipal. Son documentos relacionados con un impuesto fiscal llamado "pesillo de la seda», que era una correduría municipal que gravó la materia que llegaba a la ciudad para ser tramada con un valor mínimo de seis maravedíes por cada libra. El montante total experimentó una evolución bastante inestable, en el que se denotan bajadas y pequeñas recuperaciones, durante el periodo comprendido entre los años 1650 y 1680 . Desde luego, los augurios que pronosticaban malos tiempos en el sector textil produjeron una abstención de los obligados y arrendadores a la hora de ajustar su valor en las subastas e hizo que la renta tuviera que ser administrada y recaudada por el ayuntamiento. El comportamiento que tuvo durante el periodo mencionado fue el siguiente: un obligado se adjudicó el pesillo en el año 1650 por 2.138 .260 maravedíes, mientras que, en 1670, otro sólo ofrecía la suma 1.770.140; de tal forma que, en el transcurso de veinte años, hubo una pérdida del doce por ciento, que sin ser ostentosa es importante para determinar que era un síntoma de la depresión del sector. Durante el año 1679 estuvo en administración, al no competir postores a su recogida, y la recaudación ascendía a $1.430 .023 \mathrm{mrs}$. Esta vez la reducción es de casi un veinte por ciento. Al año siguiente se empleó el mismo sistema perceptivo y el ayuntamiento volvía a recaudar una disminuida cifra, que ahora ascendió a 800.292 mrs., un cincuenta y cinco por ciento menos que la anterior recaudación. Durante el año 1681 únicamente se ingresaban $333.829 \mathrm{mrs}$, lo que indica que el retroceso de la actividad era bastante profundo. En el año fiscal de 1683 subió hasta $701.420 \mathrm{mrs}$, lo cual evidencia un incremento de más del doble con respecto al periodo anterior, aunque volvió a caer hasta 640.867 mrs en el año 1686, pero remontó en 1697 a un millón de maravedíes ${ }^{27}$. Cabe recordar que, entre 1680-84, Larruga considera que

\footnotetext{
${ }^{26}$ Los gremios llevaron a las Cortes de 1683 unas pretensiones de signo proteccionistas. Pedían que se estableciesen medidas prohibitivas para que los comerciantes de seda no intervinieran en la comercialización de otros géneros. Los asociados gremiales, querían vender su producción con plena libertad, sin la competencia ni la supeditación a los mercaderes, y comprar la materia prima sin pasar por comisionistas MONTEMAYOR, Tolède..., p. 231.

27 AMT, Cuentas de Propios y Arbitrios, siglo XVII, caja 19. Arbitrios, 1602-1675. El impuesto llamado seis al millar lo pagó la seda, torcida y sin torcer, hilada o en pelos, urdida, capillejos y teñidas, excepto la llamada seda de moriscos y la seda de madeja. Archivo Secreto, cajón 6, leg. 1, doc. 20, Ejecutoria a favor de la ciudad de Toledo, tocante a la renta de seis al millar de la seda, año 1626. SANTOS VAQUero, Memorial del mercader..., p. 165, apunta que en 1626 entran en la ciudad
} 
hubo pérdidas por valor de 1.400 telares, tanto en ancho como listonería, con mayor incidencia en 1680 que en los tres años posteriores, lo cual representó un periodo de paulatina recuperación.

Muy similar sería el comportamiento que tuvieron los ingresos de la correduría de la seda de la tierra. Por poner un ejemplo basado en sólo dos puntos de referencia cronológica, los ingresos de 1681 fueron inferiores en un sesenta por ciento a las cantidades recaudadas en 1679. La apreciación que hizo Larruga al afirmar que la fabricación de medias se redujo de cien mil pares a cuarenta mil en los años anteriores a 1683 , junto con los valores mencionados con anterioridad, denotan los malos tiempos que atravesaban los dos artes de la seda hasta después del año $1692^{28}$.

Hay otra evidencia que no conviene olvidar y es la siguiente. Los arrendadores de rentas, los llamados obligados, buenos conocedores de la situación y de la marcha de los acontecimientos, desestimaron también participar en las subastas, aún siendo muy sustanciosos los prometidos que podían obtener, cuando presentían que la situación era desfavorable. De aquella cautela es fácil deducir que eran contadas las posibilidades de obtener plusvalías. En semejantes situaciones era el ayuntamiento el que se encargaba de efectuar la recaudación fiscal, que hacía bajo el sistema llamado administración, lo cual originó numerosos problemas, como el encarecimiento de los costes de recaudación y la imposibilidad de percibir lo necesario para pagar los réditos de los censos ${ }^{29}$.

Por otro lado, el agravamiento impositivo contribuyó a incrementar la circulación clandestina de seda. Numerosos mercaderes aprovechaban los vaivenes y, en vez de entrarla para tejer en la ciudad, la remitían a los pueblos cercanos, en lo que tenían concertada su confección con tejedores al margen de la rígida normativa toledana. El producto final, quizá mezclado con feliseda, hiladillo o trama cruda, era introducido solapadamente en Toledo como si se hubiese hecho en sus telares y después salía mezclado entre los originales. Lo expone la Real Cédula de 1691 sobre los veedores y los sobornos que estos recibían para dar como buenas tramas, marañas, hilazas e hiladillos, incluso daban por buenos hilos de seda que había sido engordados mediante la introducción en el proceso del teñido de aderezos espurios, «y los texidos que se fabricavan con dichas sedas y malas tinturas salían gruesas, toscas, sin lustre y de poca duración, porque se abrían y pudrían a poco tiempo».

\footnotetext{
150.000 libras de seda, mientras que en 1651 se consumían 104.375 libras. He aquí algunas cifras parciales encontradas en otra fuente. Entre marzo de 1660 y febrero de 1661 el derecho de seis al millar registró una entrada de 62.259 libras de seda de Valencia y Murcia, más otras 2.130 libras de seda de la tierra. AMT. Cuentas de Propios, 1640-1659, caja 2132.

28 AMT. Corredurías, años 1679-1704. LARRUGA: Memorias politicas..., t. VII, pp. 214.

29 Comenzó a cobrarse en 1660 con destino a reedificar la Audiencia de la plaza de Zocodover. Con sus rendimientos se pagarían los intereses de dos censos y amortizar los principales. RODRíGUEZ DE GRACIA, Hilario: «Bienes embargados y rentas municipales en Toledo», Anales Toledanos, XXXIII (1996), pp. 63-82
} 
A la hora de buscar las causas que provocaron el colapso en la actividad sedera, por si ésto no fuera ya de por sí grave, no hay que olvidar la importancia que tuvo la subida experimentada en el precio de la materia prima, en ocasiones sobrecargado por las dificultades del transporte y encarecido por la alteración del valor del oro y de la plata ${ }^{30}$. Los compradores debían pagar en origen la seda a los productores mediante reales de ocho o en ducados ${ }^{31}$ y los cambios de esos dos metales oscilaron al alza en casi toda la mitad del siglo, lo cual producía unos costes añadidos para los compradores, al tener que abonar un mayor premio a quienes convertían las monedas de vellón. Estos cambistas, con dificultosas evidencias todavía para situarlos en el grupo de los financieros, fueron individuos adinerados, buenos conocedores del mundo comercial por haber actuado con anterioridad como mercaderes, entre los que cabe situar a Juan Calderón de la Barca o Francisco Sanz Tenorio. Ambos, junto con otros de menor categoría, hicieron del cambio su industria. Por otro lado, la fuerte inflación de algunos años se transmitió negativamente al factor trabajo. Y es que los maestros que no pudieron hacer frente al incremento del coste de la materia decidieron limitar la producción y dejar sin trabajo a numerosos oficiales. Siguiendo esa inercia los mercaderes limitaron los créditos a la producción, mientras que los tejedores desempleados, en un intento de supervivencia, aceptaron cualquier encargo, aunque fuese a cambio de recibir un precio menor al establecido por el factor trabajo.

Una dinámica tan compleja también producía repercusiones sobre las ventas. Las que se hacían aplazadas quedaron bastante constreñidas y un alto número de ellas quedaban suspendidas por la falta de numerario. Los proveedores no aceptaban liquidaciones de ventas mediante instrumentos de pagos aplazados, obligaciones y vales, y exigían que el abono de cualquier transacción se hicieran en dinero contante y sonante. La situación experimentó un mayor agravamiento cuando se retrasaron los pagos de los géneros enviados a Indias. Muchos mercaderes tuvieron que afrontar la carencia de efectivo y quienes no consiguieron un crédito, o nuevos aplazamientos, tuvieron que declararse en quiebra. Para evitar situaciones semejantes, restringían los créditos y vendían sólo a los clientes que efectuaban los pagos al contado, ya que les resultaba más beneficioso mantener la mercancía en el almacén, donde se revalorizaba, en vez de hacerlo mediante un sistema aplazado, que suponía incrementar las cifras del activo pendiente de cobro. Los individuos dedicados al comercio eran conscientes que las prórrogas frenaban la rotación del capital a la vez que disminuía sus tasas de ganancias y limitaba el crecimiento de su actividad.

A toda la problemática del sector falta añadir la importancia que tuvo la perdida de valor de la moneda en 1680 , de gravosas secuelas para los artesanos

30 SANTIAGo Fernández: Política monetaria..., pp. 241-8.

31 La situación monetaria y política en SANZ AYÁN, Carmen: Los banqueros de Carlos II. Valladolid, 1989, pp. 278-283.

Hispania, LXII/1, núm. 210 (2002) 65-112 
que compraban seda en hilo, más que nada porque vieron disminuir sus beneficios, al tener dificultades para repercutir. la subida en los géneros que fabricaban por la intervención que la autoridad municipal ejerció sobre el precio de venta ${ }^{32}$. En los años ochenta, la contracción que sufrieron los metales preciosos produjo un movimiento alcista del premio - tipo de cambio- de la plata y provocó un retraso en los pagos de consecuencias imprevisibles. Por los testimonios documentales se infiere que numerosos acreedores incumplieron los vencimientos acordados, a la espera de conseguir nuevas prórrogas de sus proveedores, con los que ajustaron las liquidaciones en plata. Al unísono, los deudores de menor entidad, aquellos que pagaban en vellón, tampoco tuvieron oportunidad de hacer frente a sus deudas y debieron enfrentarse a las exigencias judiciales de sus acreedores, lo que hizo que aumentasen los concursos y embargos. Tanto lo uno como lo otro dificultó la comercialización de la seda y constriñó la actividad artesanal y mercantil.

\section{MERCADERES Y FABRICANTES}

La práctica comercial, aun enfrentándose a tantas dificultades, resultó lucrativa para los que quisieron arriesgarse, lo que les permitió, en momentos de tanta incertidumbre, obtener considerables plusvalías. Los que estaban en una mejor situación para aprovecharse de las oportunidades eran los fabricantes; muchos más eran los que utilizaban métodos poco convencionales, como fue acaparar seda sin confeccionar y no venderla a no ser a mayor precio del que establecía el mercado ante la mucha demanda y poca oferta, o aquellos otros que encargaban los trabajos a tejedores con salarios bajos y les recomendaban mezclar calidades de seda muy diversas. Los que no especularon con esas prácticas, lograban unos beneficios bastante más exiguos: Sortear las múltiples rémoras no fue nada fácil. Hubo mercaderes o sociedades que efectuaron transacciones con inmejorable habilidad: compraron de forma clandestina la seda, la tejían bajo procedimientos de discutible calidad o enmarañaron los utensilios que servían para confeccionarla. Esa estratagema consistió en encargar las urdimbres a maestros hábiles que utilizaban en la fabricación un número de púas inferior a lo ordenado en la ordenanzas gremiales. A esas telas nunca llegaron a ponerlas el precinto que indicaba su imperfección, sino que vendieron como auténticos los terciopelos ligeros que llevaban engomados, las piezas que estaban faltas de peso o las que tenían imperfecciones en el teñido! La entrada ma-

32 Collantes PÉrez-Arda, Esteban y Merino Navarro, J. Patricio: «Alteraciones al sistema monetario de Castilla durante el reinado de Carlos II", Cuadernos de Investigación Histórica 1 (1977), pp. 74-97. El objetivo consistía en dotar al comercio de numerario, sólido y estable, cuya relación con la moneda de plata estuviese ajustada. Entre las quiebras de mayor proyección hay que situar la Nicolás y Manuel Díaz Gutiérrez, acaecida en 1683. ARCHIVo Histórico ProvinCiAL DE TOledo (AHPT). Protocolo 3808, fol. 144, año 1683-84, escribano Jerónimo Pérez de Aris. 
siva de tejidos foráneos con los que competir pudo incrementar tales comportamientos, porque su uso y práctica fue más frecuente entre fabricantes y mercaderes intermediarios y apenas practicado por los artesanos agremiados, que eran más respetuosos con la calidad del producto que salía de sus telares.

No es posible cuantificar el número de mercaderes o compañías que actuaron siguiendo mañas tan discutibles; lo cierto es que los fraudes afectaron notablemente al sector, hasta tal extremo que provocaba un retraimiento irreversible a partir de la década de los años setenta. La revisión de las ordenanzas hecha en 1684 denota la preocupación del gremio por el alto volumen de géneros clandestinos que había en manos de los mercaderes. Para evitar los fraudes, los maestros solicitaron nuevas medidas, que serían recibidas con muchas reticencias por quienes comercializaban con géneros de seda poco convencionales, que en una alta proporción eran jurados del ayuntamiento. El gremio siempre buscó obtener un producto de calidad y exigió que los tejidos llevasen un número determinado de púas en géneros como las colonias, listones y reforzadas, pero ciertos mercaderes, que trabajaban con algunas menos, aseguraban que la reputación de los tejidos no quedaba menoscabada. La defensa a ultranza de tal postura sólo es explicable si se tiene en cuenta que una rebaja en el precio de coste revertía en mayores ganancias para el fabricante. Los inmediatos perjudicados serían los maestros que siguieron las cláusulas gremiales en toda su integridad, al no poder competir con los adulteradores que colocaban el sello de Toledo en sus artículos y los comercializaban como genuinos. En 1689, los veedores del gremio de la seda estaban desbordados por la cantidad de tejidos fraudulentos que había en el mercado. Como procedimiento defensivo para limitar su proliferación solicitaban repetidas pragmáticas reales y anunciaron contundentes castigos en metálico para los transgresores. Esta disputa tuvo un desarrollo desigual, con demasiados altibajos, que se tradujo en un rotundo fracaso para los agremiados. No obstante, el arte mayor recibió algunas bocanada de esperanza en su empeño. En una de las pragmáticas se prohibía la venta de lanzaderas a personas afincadas fuera de la ciudad, así como el pago de multas considerables a quienes las sacasen extramuros de forma subrepticia. Sufrió, en contrapartida, un fracaso implacable cuando no pudo impedir que los maestros que abandonaban la ciudad, e iban a otras localidades cercanas a establecer los telares, perdieran el privilegio de vecindad. La verdad es que, en este sentido, el gremio contó con pocas armas para erradicar la fabricación fraudulenta, al ser una operación que requería de estrecha vigilancia y mucho apoyo municipal ${ }^{33}$.

Desde el siglo XVI, los mercaderes de lonja actuaban como proveedores exclusivos de la seda en bruto y lo hacían bajo una doble modalidad: comisionistas y distribuidores del producto que compraban en el Levante y traían a vender a Toledo. La materia era adquirida, por su cuenta y riesgo, en Murcia

33 AHMT. Caja 2.293, Cuaderno segundo de las órdenes tocantes al Arte de la seda, 1685-1691.

Hispania, LXII/1, núm. 210 (2002) 65-112 
durante la mayor parte del siglo $\mathrm{XVI}^{34}$, mientras que en la segunda mitad del XVII los puntos de compra se trasladaron a pueblos valencianos como Alcudia, Algemesí, Onteniente y Gandía ${ }^{35}$. Otras partidas, a veces de un valor nada desdeñable, procedían de Talavera y Pastrana ${ }^{36}$, al pagarla a menor precio que la llamada de almendra; esto es, la de óptima calidad. Posiblemente, el cambio de la seda proveniente de Murcia por la de Valencia tenga mucho que ver con las mezclas, porque al ser las valencianas de mayor calidad hacía menos perceptible las mixturas. El aumento de la demanda de la seda de una categoría inferior estuvo en función de las necesidades que tenían los maestros menos rigurosos, y es muy probable que los más expertos lograse dar tan alta calidad en los géneros que pasasen inadvertidos a los compradores, incluso a los exigentes, y planteasen dificultades de apreciación a los veedores del gremio ${ }^{37}$.

El comisionista de seda toledano actuó como intermediario entre un proveedor y un maestro del arte y su comportamiento estuvo encuadrado en las siguientes directrices. El mercader procedente de Valencia llegaba con la mercancía a la ciudad y la depositaba en "el mesón de la seda», el lugar donde solían hacerse todos los intercambios. Concretada la operación por el comprador y vendedor, la siguiente fase era acordar la manera de liquidarla y casi siempre se decantaban por hacerlo mediante un aplazamiento a corto plazo, cuyo cobro quedaba garantizado con la firma de ambos puesta en una escritura de obligación, en la cual quedó constancia del valor total de la operación y de la forma de pago.

${ }^{34}$ Pérez PiCazo, M. Teresa y Lemeunier, Guy: «El caso murciano», España y Portugal en las rutas de la seda. Barcelona, 1996, pp. 101-119 y MirAlles MARTíneZ, Pedro: Seda, trabajo y sociedad en la Murcia del siglo XVII. Murcia, 2000. La existencia de comisionistas de seda murciana queda documentada en una información que facilita Cristóbal Martín. AHPT. Protocolo 3480, fol. 1164, año 1652, Sebastián López.

35 HuRTAdo DE TOLEDO, Luis; «Memorial de algunas cosas notables que tiene la Imperial ciudad de Toledo», PAZ, Ramón y VIN̄AS, Carmelo (transc): Relaciones históricos geográfico estadísticas de los pueblos de España. Madrid, 1963, t. III, p. 525 da información sobre la procedencia de la seda que se gasta en la ciudad. MARTínez SANTOS, Vicente: Cara y cruz de la sedería valenciana, siglos XVIII$X I X$. Valencia, 1991, p. 48, ratifica la procedencia y la localiza en Valencia, Orihuela, Alcira, Carcagente, Algemesí, etc. CASEY, El reino..., p. 88 incluye a Játiva como un núcleo de producción importante.

${ }^{36}$ Hubo un periodo en que numerosos mazos de seda procedían de un entorno inmediato como eran las localidades de Cardiel, San Pablo, Cebolla, Nombela, Alcaudete. Ese material pagó un impuesto llamado seda de forasteros, un arbitrio incluido en un conjunto fiscal denominado por los contadores municipales peso del mercado.

37 LARRUGA: Memorias políticas..., t. VII, pp. 241. Los mercaderes pretendían que los fabricantes no comerciasen con la seda en rama, al considerar que era un oficio de regatones. Por una información de 1646, un tal Mateo López, en quien recayó el remate del pesillo de la seda, se sabe que la seda en rama la acaparaban los denominados comisionarios para remitirla a Sevilla y Madrid. AMT. Seda, legajo 1, impresos de 1616-1678. La solicitud para reducir los derechos impositivos de entrada en AMT. Cartas, año 1646.

Hispania, LXII/1, núm. 210 (2002) 65-112 
Si el productor no vendía una parte de la mercancía, antes de volver a la localidad de origen con el sobrante optaba por dejársela a un comisionista en depósito, casi siempre un mercader solvente que aceptaba el encargo de ajustar su transacción al precio indicado por el dueño, incluso efectuaba el posterior cobro, todo ello a cambio de un corretaje ${ }^{38}$. En el caso de que el precio de la materia descendiese de forma rápida, el comisionista suspendía la venta para evitar una pérdida considerable al remitente, siguiendo las pautas de una norma que alcanzó la categoría de precepto no escrito. Así se comportó el jurado Juan García de García Alonso en septiembre de 1652, cuando el lonjista valenciano Leonardo Pintor le dejó en depósito tres partidas de seda para su venta. Juan interrumpió la liquidación porque bajó de forma muy rápida el precio y requirió la autorización del valenciano a través de un informe judicial, donde le indicó el precio al que se pagaba cada libra ${ }^{39}$.

Una de las acusaciones más significativas que hicieron los artesanos a los comisionistas es que estrangulaban el mercado cuando la demanda de seda sin hilar o ya preparada aumentaba, porque reducían la oferta o impedían que los valencianos entrasen el género en la ciudad. Actuaban como regatones porque les compraban la mercancía que transportaban a un precio fijo y la almacenaban a la espera de que escasease para hacer oscilar al alza el precio. Una práctica también frecuente entre los mercaderes que traían la trama lista para entrar en los telares, ya que solían ponerse de acuerdo con suma facilidad y establecían un precio de venta. Entre los años sesenta al ochenta fue tan perfecta la coordinación que dio origen a un monopolio del que formaron parte activa Francisco Alzamora, Martín Canut, Matías Fuster, Pedro Dalmau, Roque Portel o Timoteo Ferrer, todos ellos con raíces valencianas ${ }^{40}$. Su táctica de trabajo consistía en comprar la materia en origen, pagarla en plata, transportarla hasta Toledo, venderla al contado, o aplazada, y asumir el riesgo del cobro. Si aparecía por la ciudad un productor desconocedor de sus prácticas, ejercían la función de comisionistas, un servicio que también prestaron a los lonjistas valencianos que les enviaban partidas previamente vendidas. Al unísono, ellos comerciaban con una amplia serie de productos transformados, los cuales remitían a sus clientes de Murcia o a localidades de la región valenciana, en un comercio de retorno que exasperaba y que quisieron limitar sus colegas toledanos ${ }^{41}$.

38 Roque Portel, en 1665, figuró como comisionista de unos mercaderes de Játiva apellidados Masip. Hay un documento de cobro donde aparece un envío por valor 19.197 rls, que será liquidado en plata doble mejicana. AHPT. Protocolo 272, fol. 501, año 1665, Martín de Villaseñor.

39 AHPT. Protocolo 144, fol. 152, año 1650, Eugenio de Valladolid.

40 Algunos toledanos, entre los que cabe destacar a Tomás de Alcocer, Marcos Pérez, Juan de Segovia Urquizu o Jaime de Mora se ocuparon ininterrumpidamente de la actividad. AHPT. Protocolo 3454, fol. 373, año 1652, Pedro de Ugalde. LARRUGA, Memorias..., vol. VII, p. 241 muestra las luchas de los mercaderes para impedir que los fabricantes comerciasen con seda en rama.

41 Franch Benavent, Ricardo: «La atracción de los mercados andaluz y colonial sobre el comercio valenciano dieciochesco", La burguesía de negocios en la Andalucía de la Ilustración. Cádiz, 1991, t. I, pp. 71-83. Constata la existencia de corresponsales, pp. 76-77, para vender productos valencianos. 
La seda llegó, casi siempre, a Toledo tramada e hilada, lista para la venta a fabricantes, mercaderes y artesanos; también vino en capullos, ya hervidos, porque así conservaba mejor la sericina. Viajó embalada en fardos para impedir que se deteriorase con el transporte $e^{42}$. En los documentos aparecen tres clases de seda. Una es la llamada de capillexo; eso es, la que viene todavía en un capullo formado por el gusano muerto. Otra es la denominada en pelo, constituida por cabos y marañas crudas, que necesitaba de ciertas intervenciones, como el hilado y el teñido, operaciones ambas a realizar por mujeres en tornos caseros, bastante rudimentarios, cuya pieza principal era un pedal que al accionarlo la hilandera giraba la rueda de la devanadera donde estaba enrollándose la madeja. La tercera clase se llamó seda de hiladillo o hilo. Era vendida ya teñida e incluso tramada y casi siempre fue remitida en madejas devanadas. Una vez en la ciudad, sus fibras eran sometidas a un nuevo proceso de doblado y torcido ${ }^{43}$. Si el hilo presentaba manchas o defectos se denominaba seda ocal. La comercialización de esta variedad inferior a la calidad de referencia representó cantidades apreciables por dos razones: su facilidad para combinarla con la de almendra y su dificultosa diferenciación en géneros confeccionados, sobre todo en medias, listones y reforzadas, cuyo tejido se realizó en telares pequeños llamados angostos o telaricos 44 .

Entre los protocolos de las décadas de los años cincuenta y sesenta abundan las referencias sobre partidas de sedas sin devanar, que eran compradas por fabricantes y entregadas a hiladores para que efectuasen el torcido, para lo cual utilizaron un instrumento llamado azarja. Estaba constituido por dos discos, unidos por cuatro costillas, con un agujero en el centro para que pasase el huso ${ }^{45}$. Una vez que era torcido el hilo - a partir de ahí a la seda se le daba el nombre de refrenida - se le aportaba la tonalidad adecuada, cuyo tratamiento hacían los tintoreros en los tintes cercanos al río, a veces de forma independiente o trabajando para un mercader, con un salario tasado de antemano ${ }^{46}$. El tin-

${ }_{42}$ AHPT. Protocolo 502, fol. 97, año 1681, escribano Juan Jiménez Hocos. En este legajo está el registro de la compañía que posee Antonio Garamato. Se hizo cuando casó con María Guerrero Valvellido. En él aparecen las tramas y los pelos que se entregaron al tintorero, así como el abono de las tinturas en diversos colores, amarillo, tonos verdoso, azules y negros. MONTEMAYOR, La seda en Toledo..., p. 124, relaciona los componentes químicos utilizados en el teñido.

43 Martínez Santos, Cara y cruz..., pp. 183-185, enumera los procesos de hilatura en tres modelos diferentes. La concentración de tareas en ZOFío LlóRENTE, J. Carlos: «Organización de la producción manufacturera en Madrid durante el reinado de Felipe II», Torre de los Lujanes, 33 (1998), pp. 167-200, sobre todo en 197. CASEY, El reino..., p. 88, distingue estos tres tipos: seda fina, adúcar y esqueixada.

${ }^{44}$ AMT. Archivo Secreto, leg. 4, documento 28. En una real cédula prohibiendo revender la seda en madejas se mencionan las mezclas en los terciopelos.

${ }^{45}$ En el título 138 de las Ordenanzas de 1574 se acusó a los mercaderes de limitar los procesos del torcido para abaratar los costes, aun perjudicando la calidad del producto.

${ }^{46}$ Uno de los tintes importantes estuvo situado en San Cipriano, el llamado de la Galera. Había en él bastantes vasijas que solían alquilarse de forma independiente. AHPT. Protocolo 3643 , 
tado era una operación muy especializada y requirió de bastante precisión debido a las dificultades que entrañaba el obtener los colores a gusto con la demanda. Por último, el torcido tuvo varias modalidades: a modo de trenza, en hilos, para realizar ojetes en cordones y flecos, y los designados caireles que son los flecos utilizados para adornar los vestidos ${ }^{47}$.

\section{MAESTROS TEJEDORES VINCULADOS A LOS MERCADERES}

Dos grupos gremiales, comúnmente conocidos como artes, intervinieron en el proceso de elaboración textil: el mayor de la seda, donde se integraban los tejedores de terciopelo, damasco, fondos, piñuelas, rasos, y el menor de la seda que congregó a los listoneros y cordoneros ${ }^{48}$. Los artículos que salían de los talleres de ambos gremios se ajustaban a unas normas muy estrictas de fabricación. De la observancia se encargaron los veedores y maestros más antiguos y les ayudaban otro dos personajes denominados sobreveedores, cuya designación hacían los regidores y los jurados del concejo. Fiscalizaban la calidad de los tejidos y podían sancionar las transgresiones con multas pecuniarias, a la vez que requisaban el género imperfecto para quemarlo ${ }^{49}$.

Durante gran parte de la segunda mitad del XVII, los llamados mercaderes de escritorio -los que dieron a labrar en función de la demanda-, también nominados fabricantes, cedían la materia a los tejedores, hilada y teñida, para que ellos confeccionasen los tejidos según la normativa aprobada por la ciudad y recogida en las ordenanzas del arte ${ }^{50}$. La técnica llamada xinovisca, por escoger un ejemplo, se fabricaba con 21 ligaduras, con 40 púas por ligadura y ésta a su vez con 80 hilos, es decir, dos hilos por diente. La destreza del operario sería un elemento esencial en su cualificación, porque para la urdimbre de ciertos teji-

fol. 1221, año 1673, Martín de Villaseñor. El hilado se realizaba por cuenta de los mercaderesfabricantes, en Ibídem, 3532, fol. 484, año 1665, Nicolás López. Obligación entre el hilador Diego Crespo y el jurado Juan de Olmos que le da cincuenta libras y dos onzas de seda en madeja de Murcia, más 4.028 rls en dinero.

47 SALADRIGAS CHENG, Silvia: "Los tejidos en Al-Andalus: siglos IX-XVI. Aproximación técnica», España y Portugal en las rutas de la seda. Barcelona, 1996, pp. 75-98, muestra el proceso que se seguía para conseguir los tonos.

48 Son los nominados telares angostos. La pluralidad de tejidos elaborados por unos y otros en GARZÓN PAREjA, La industria sedera..., pp. 204-213.

49 MARTÍN GAMERO, Antonio: Ordenanzas para el buen régimen y gobierno de la muy noble, muy leal e imperial ciudad de Toledo. Toledo, 1858, títulos 138 y 139. Más concretos son los artículos de SÁEZ SÁNCHEZ, Emilio: «Ordenanzas de los gremios de Toledo», Revista del Trabajo 5 (1946), pp. 495505. SAN ROMÁN FERNÁNDEZ, F. Borja:««El libro de las ordenanzas del Arte Mayor de la Seda», Toledo, Revista de Arte, 215 (1925), pp. 1076-78.

50 AHPT. Protocolo 3897, fol. 963, año 1699, Juan Jiménez Hocos. Informe aportado por Juan Becerril y Cía, al solicitar una certificación sobre la calidad de unas telas compradas en Sevilla, las cuales pretendía que llevasen el sello de autenticidad.

Hispania, LXII/1, núm. 210 (2002) 65-112 
dos requería usar tres lanzaderas a la vez o utilizar varias clases de hilos como ocurría con el fondo y el pelo de los terciopelos.

Una vez confeccionadas las piezas eran examinadas por los veedores con el fin de obtener su normalización. Si surgía alguna duda sobre la autenticidad, los veedores debían realizar las mediciones correspondientes y certificar su grado de calidad ${ }^{51}$. Es probable que los vigilantes actuasen con cierta transigencia a la hora de observar las normas y algunos tejidos fuesen homologados con relativa tolerancia, quizá con sobornos de por medio. La condescendencia pudo ser más frecuente en las etapas más críticas, con el fin de no dejar en paro a sus compañeros. Sabían que un buen número de maestros, los que trabajaban con el telar cedido por un mercader, aunque la normativa gremial exigía que todos tuvieran uno propio, urdían tejidos de óptima calidad o los intercalaban con otros inferiores, porque esas eran las instrucciones que recibían de su patrono ${ }^{52}$.

Las operaciones de hilar, tejer y devanar la seda fueron realizadas en ámbitos domésticos, preferentemente por maestras residentes en los pueblos ${ }^{53}$. Hay una razón para que así fuese. Los mercaderes preferían a las mujeres porque las pagaban un salario inferior al que abonaban a los hiladores que vivían en la ciudad. Aquel copioso potencial de mano de obra disponible gozaba de gran habilidad en el hilado y en el tramado ${ }^{54} \mathrm{y}$ constituyeron un modelo productivo conocido con el nombre de «sistema doméstico», «verlagssytem», «putting-out system» ${ }^{55}$. Una vez torcida y tintada la seda, se encargó de su venta un lonjista

51 AHPT. Protocolo 3449, fol. 53, acusación contra Martín de Veizama por introducir en Toledo picotillos falsos.

52 Los géneros sólo podían ser urdidos por maestros examinados. AMT. Seda, 2293, Ordenanzas de Arte Mayor promulgadas el 18 noviembre de 1683 y publicadas en 1705, con las normas para confeccionar damascos, terciopelos, rasos, etc. Entre la documentación hay un cuaderno que corresponde a las de delaciones del año 1683. Allí aparece indicado el número de portadas que llevarían los géneros fabricados en Toledo.

53 El sistema de trabajo a domicilio de los tejedores en ARANDA, F. José: «Mercaderes de Toledo en el Seiscientos, Bases económicas y "status" sociopolítico", Investigaciones Históricas 12 (1992), pp. 90-3 y MONTEMAYOR, Tolède..., p. 229-231. En Fuensalida, una localidad cercana a Toledo, existió una cofradía llamada del Rosario y a ella pertenecían numerosos tejedores de damasco. Protocolo 3124, fol. 141v, año 1642, Rodrigo de Hoz. La entidad religiosa de los maestros del arte mayor en Toledo fue la cofradía de Nuestra Señora del Rosario.

54 El trabajo femenino es objeto de análisis en el estudio colectivo titulado: Women's work and the family economyc in bistorical perspective. Manchester, 1990. Importantes son las aportaciones de NADAL, Jordi y CATALÁN, Jordi.; La cara oculta de la industrialización española. Madrid, 1994. BoRDerías, Cristina y CARRASCO, Cristina: Las mujeres y el trabajo. Rupturas conceptuales. Madrid, 1994, pp. 77-91.

55 GonZÁlez ENCISO, Agustín: "La industria dispersa lanera en Castilla en el siglo XVIII», Cuadernos de Investigación Histórica, 1 (1978), pp. 269-289. THOMPSON, J. K. F.; "Protoindustrialization in Spain", European Protoindustrilazation, en OlgIvIE, S. C. y CERMAN, M. (eds.); Cambridge, 1996. Comerciantes y financiero buscaron a través de verlagssystem una nueva vía para ampliar su negocio, según GoNZÁLEZ ENCISO, Agustín: «La promoción industrial en la España 
o un mercader. Con frecuencia los adquirentes fueron mercaderes de géneros confeccionados y cedían las hilaturas a los tejedores que trabajaban para ellos, después de pesarlos con gran fieldad para evitar estafas ${ }^{56}$. En el caso de que la seda en hilo la comprasen los maestros independientes, los no sometidos al mercader, tejían artículos muy demandados que eran vendidos directamente a los consumidores.

Lamentablemente, el número de tejedores que operaron con autonomía fue cada vez menor, ante la sencilla razón de que tuvieron una capacidad económica restringida. Eran bastante numeroso el grupo de los que contaban con bienes limitados, o lo que es igual solvencia, lo cual les incapacitaba para aguantar un capítulo voluminoso de deudas pendientes de cobro. Tales dificultades les excluían de los circuitos comerciales; sin embargo, una alternativa consistía en trabajar para maestros solventes o para mercaderes fabricantes. De ellos recibía el tejedor un telar, que en los documentos aparece como vendido, sin serlo, con la condición de que el recipiendario trabajase para el dueño del artificio, comprometiéndose a pagarle el artificio cuando se lo demandase el vendedor o devolvérselo si no cumplía el pacto. Hay otra razón, además de la económica, para explicar aquella transmisión subrepticia y se fundamenta en que las ordenanzas del gremio limitaban la propiedad de elementos fabriles, «a los que pudiera instalar en su casa» un maestro examinado.

Similares eran las condiciones que estipularon para efectuar los encargos de obra. Una parte entregaba a la otra la materia prima sin urdir y una cantidad en dinero a cuenta del salario. El receptor se comprometía a confeccionar la pieza, o pagar en 'caso contrario su valor al dador, que la retiraría una vez elaborada $^{57}$. Semejante compromiso solían suscribirlo los tejedores entre sí, pero más usual resultó concertarlos entre mercaderes y tejedores. Eugenio Dávila, un maestro sedero bastante rico, incluyó en su testamento el siguiente comentario: «Declaro que diferentes maestros y oficiales del arte de la seda y maestras de colonias, que an tenido cuenta en mi escritorio, me deven algunas cantidades de seda y maravedíes por quenta del libro y sin ellas. Y porque Dios me perdone, se las remito y perdono.... ${ }^{58}$.

moderna: intervencionismo público e iniciativa privada», Industria y Época Moderna, dirigido por Ribot GARCíA, Luis y De ROSA, Luigi. Madrid, 2000, p. 22.

56 Las tres variedades de hilos eran: orcoyo, utilizado para dar pelo a las urdimbres de terciopelo, tramas, paris y alcadí.

57 La combinación de actividades para diversificar riesgos la apunta CASADO ALONSO, Hilario: Señores, mercaderes y campesinos. La comarca de Burgos a fines de la Edad Media. Valladolid, 1987, pp. 502-6.

58 AHPT. Protocolo 280, fol. 1186, año 1672, Martín de Villaseñor. Aspectos negativos como la falta de capital, atomismo del oficio, en BERNAL, Antonio, COLLANTES DE TERÁN, Antonio y GarCíA BAQUERO, Antonio: «Sevilla. De los gremios a la industrialización», Estudios de Historia Social, 56 (1978), pp. 7-307. La escasez de capitales fijos lo observa GARCía SANZ, Angel: «Mercaderes hacedores de paños en Segovia en la época de Carlos V: organización del proceso productivo y estructura del capital industrial», Hacienda Pública española, 108-109 (1987), pp. 65-79. 
Bastante más problemático es conjeturar sobre el contenido de los tratos verbales. Los conciertos de ese tipo debieron abundar al considerar los maestros tejedores que la dependencia les resultaba más ventajosa que operar de forma autónoma. Las razones de esa decisión son complejas y primaban las económicas. En ese caso, el mercader, o una compañía mercantil, asumían el coste de la materia prima y el de los flujos de cobro, dos elementos bastante onerosos para el tejedor. El último resultó más pesado por lo desusado que era establecer transacciones al contado. Es más, una vez estipulado el vencimiento resultó frecuente tener que prorrogar el pago a una fecha posterior, lo que producía un incremento de los índices de endeudamiento ${ }^{59}$. De forma un tanto abusiva, los vencimientos de pago podían demorarse tres, seis o doce meses y mayor tiempo, siempre en función de la confianza que tuvieran deudor y acreedor ${ }^{60}$. Una postergación tan dilatada de los pagos facilitó la dependencia entre mercader y tejedor, con mayores ventajas para el último que para el primero. Trabajar para un mercader le permitía prescindir de hacer inversiones en activos fijos, así como no adquirir instrumentos fabriles, ni mantener elevado el activo circulante exigible y, lo más importante, no asumían pérdidas por morosidad ${ }^{61}$.

En el arquetipo de producción descrito, los costes directos tuvieron una considerable importancia, más que nada si la materia experimentaba una oscilación alcista debido a la reducción de la oferta. Los artesanos difícilmente pudieron repercutir el incremento de los costes primarios sobre los tejidos ya confeccionados, pues las subidas no podían traspasarlas al precio final que pagaba el consumidor, al estar sometido a un control que periódicamente ejercía la autoridad municipal. Ante esas circunstancias, un aumento en el precio de la materia prima disminuía las posibilidades de compra de los artesanos, escasos siempre de efectivo, ya que los vendedores no concedían aplazamientos de pago si tenían asegurada la compra al contado por otros clientes ${ }^{62}$. En etapas de escasez proliferaron los tratos convenidos, efectuados la mayoría en los mesones situados extramuros, cuya mercancía entraba en la ciudad de forma clandesti-

59 Sobre los pagos a corto y largo plazo PrIOTTI, Jean-Phlippe: Los Echávarri: Mercaderes bilbaínos del Siglo de oro. Ascenso social y económico de una familia. Bilbao, 1996, pp. 81-2. DOBB, Maurice.; Estudios sobre el capitalismo. Madrid, 1984, pp. 32 y 107.

${ }^{60}$ Francisco Gómez Izquierdo es un paradigma de lo apuntado y la mejor evidencia es que en el ajuste de cuentas, en 1681, con un fabricante de sombreros de Segovia resultó deberle $3.000 \mathrm{rls}$, cuya cifra le pagaba en noviembre de 1687. Habían transcurridos seis años desde que se estableciera la obligación. AHPT. Protocolo 3743, fol. 93, año 1681, Diego Sánchez Tamayo.

${ }^{61}$ La existencia de una alta la morosidad se comprueba por los registros que efectuaban los factores. Numerosos mercaderes actuaron con precaución a la hora de conceder un crédito, aun siendo el impago castigado con severidad. Recuperar una deuda fallida era un ejercicio bastante complicado, a decir de RoDRígueZ GONZÁLEZ, Ricardo: Mercaderes castellanos del Siglo de Oro. Valladolid, 1995 , pp. 187-190.

${ }^{62}$ Los revendedores de la seda sin confeccionar provocaban el aumento del precio, a decir de FRANCH BENAVENT, Ricardo: «El abastecimiento de materias primas en la industria textil española del siglo XVIII", en Industria y época Moderna, Madrid, 2000, pp. 63-93. 
na. Hay constancia de esas maquinaciones en las denuncias que continuamente realizó el gremio de los tejedores. Esas quejas y malestar quedaron plasmadas en las peticiones que remitían al Consejo de Castilla, en las que advirtieron sobre la inoperancia para eliminar las ventas encubiertas por parte de las autoridades. El gremio, tanto el arte mayor como el menor de la seda, consideraban que tal permisividad socavaba su desarrollo ${ }^{63}$.

Dentro del grupo de los mercaderes de seda, numeroso e indefinido, hubo unos que se autonominaron fabricantes - también respondieron al nombre de mercaderes de escritorio-, que asumían la totalidad de los costes de producción y los relativos a la distribución del obraje sedero. El calificativo lo utilizaban más para distinguirse de los que sólo intercambiaban artículos, a la vez que querían singularizarse alegando que intervenían en todas las fases del proceso de transformación ${ }^{64}$. De sus dotes y competencias dejaron testimonio dos individuos, Baltasar Zornoza y Juan Vázquez de Dueñas, en un escrito presentado en calidad de recurso ante el Consejo Real, al estar en desacuerdo con una sentencia del corregidor de Tordesillas. El pleito lo motivó la aprehensión de unos géneros sin guía ni razón del fabricante que los elaboró65. Ellos, al plantear su defensa, dijeron ser los fabricantes y empleaban la expresión para puntualizar que su condición era igual a la de hombres de negocios. Al explicar en que consistían esas funciones apuntaban que, como tales fabricantes, pagaban todas las operaciones que comportaba el proceso de confección, o lo que es igual, se encargaban de comprar la seda en rama o madejas, hilar y teñirla a su costa, para una vez lista cederla a los urdidores. Después la recogían y vendían las diferentes piezas y tejidos por su cuenta y riesgo, pagando alcabalas y otros impuestos. Puntualizaron que sus funciones no eran despachar en su tienda ni tampoco ejercer un trabajo de los considerados manuales, sino que se ocupaban en exclusiva de dirigir la fabricación y la comercialización de los textiles, pues sus factores y criados eran los responsables de los demás cometidos de su negocio ${ }^{66}$. Las funciones a realizar por el factor, como se verá después, estaban reseñadas en las escrituras fundacionales de las compañías. El Diccionario de Autoridades recoge la siguiente síntesis en relación con sus deberes: «es la persona que tiene

63 AHPT. Protocolo 3643, fol. 1026, año 1676, Martín de Villaseñor.

64 Se trata de un comercio al por mayor, donde el dueño ni expide ni pesa ni mide géneros en un mostrador. Opera a través de una tienda y ese establecimiento tuvo la consideración de almacén para distribuir al por mayor.

65 Categóricamente afirmaban que no eran revendedores de géneros de seda. Hay otro ejemplo $\tan$ ilustrativo como el mencionado en AHPT. Protocolo 3778, fol. 473, año 1667. LARRUGA, Memorias..., t. VII, pp. 14-15, analizó sus funciones.

66 Cerrillo Cruz, Gonzalo: Los familiares de la Inquisición española. Valladolid, 2000, p. 102, muestra como a la hora de pretender una familiatura del Santo Oficio se tuvieron en cuenta esos condicionantes. El año 1682, por una Real Pragmática a favor de los fabricantes de tejidos, quedaron eliminadas las trabas que impedían su ascensión a la nobleza por mantener fábricas de sedas, paños, telas u otros tejidos.

Hispania, LXII/1, núm. 210 (2002) 65-112 
destinada en algún parage (el comerciante) para hacer las compras de géneros y otros negocios en su nombre».

No resulta fácil diferenciar conceptualmente a un mercader y un fabricante en función del trabajo que realizaban, ya que tanto el uno como el otro intervinieron en el proceso de fabricación con pocas disimilitudes, excepto desde el ámbito cuantitativo. Dependieron de ellos los maestros artesanos, bien por comprarles los géneros ya tejidos, bien por comprometerse a efectuar en sus telares las urdimbres que les encargaban. La tolerancia, por parte de los veedores, a la hora de visitar los almacenes, si la hubo, no debió de ser transcendental, aunque hay que tener en cuenta que muchos de los medios de producción utilizados por los tejedores, incluso por los maestros independientes, pertenecían a los mercaderes y se desconoce el alcance de aquella servidumbre. Pudo haber una relativa condescendencia sobre el ancho mínimo de las piezas, la calidad del hilo que debían utilizar o el número de urdimbres a emplear en los tejidos, sustentada en la necesidad que cada uno tuvo del contrario, al ser los veedores maestros de arte de la seda y saber los inconvenientes que sus compañeros de gremio debían superar ${ }^{67}$.

El vínculo que mantuvo unidos al mercader y al tejedor fue el telar, ya que en torno a él establecieron una serie de relaciones económicas, entre las que cabe destacar las siguientes. En primer lugar, el comerciante cedió al urdidor el ingenio y éste lo recibió en calidad de préstamo a la producción; eso si, aceptado en calidad de elemento vendido en vez de herramienta cedida. Su valor monetario no estaba en función de sus condiciones de uso, sino que se establecían en relación al tejido que se iba a urdir, terciopelos, felpas, fondos, damascos, rasos, tafetanes o mantos. Por esta circunstancia, el precio anotado en diversas obligaciones no muestra diferencias ostensibles, lo que impide valorar el precio real de los instrumentos fabriles. Es más, como la liquidación se hacía con la devolución del instrumental, los remitentes consideran siempre que era un crédito a largo plazo. Una vez fijado el valor de un telar, se anotaba en los libros contables del mercader como otra deuda más, con la excepción de que ésta tenía un vencimiento impreciso. El apunte aparecería como un elemento del exigible a largo plazo, cuya liquidación sólo podría exigirla el cedente al concluir la relación contractual, con la devolución del aparejo usufructuado o con el valor monetario estipulado ${ }^{68}$. Las dificultades, por parte del tejedor, para realizar la amortización fueron inaccesibles por el elevado precio del telar en relación al salario que perci-

${ }^{67}$ Los veedores del arte mayor inspeccionaban el número de púas, pero no ponían ninguna salvedad al largo de las piezas, si bien lo normal era que superasen el centenar de varas. AHPT. Protocolo, 3778, fol. 764 , año 1667, hay una obligación por la venta de ocho estameñas pardas con una longitud total de 1.016 varas.

${ }^{68}$ AHPT. Protocolo 156, fol. 120, año 1660, Eugenio de Valladolid. Préstamo que hizo el jurado Nicolás Suárez de Herrera a dos maestros, por valor de 250 rls, para comprar un telar de fondo.

Hispania, LXII/1, núm. 210 (2002) 65-112 
bía un tejedor ${ }^{69}$. Algunos teóricos dirán que este modelo de cesión fue desfavorable para quienes aportaban el esfuerzo, porque al aceptar las condiciones transferían al capital cualquier pretensión sobre el valor de su trabajo y se limitaban a ser asalariados del dueño del medio de producción ${ }^{70}$.

Otro elemento del sistema de dependencia lo representó la seda que el mercader entregó a su tejedor para ejecutar las urdimbres. Los hilos fueron siempre pesados en libras u onzas y quedaban contabilizados en los libros diarios por su valor monetario ${ }^{71}$. La cesión se documentaba por medio de una obligación que las partes firmaban ante el escribano público. Ambos contratantes aceptaban el documento como único justificante en posteriores entregas de materia prima y reducían las divergencias a la más mínima expresión, porque el receptor aceptaba como válido todo aquello que estuviese asentado en el libro del acreedor ${ }^{72}$. "Me obligo - refrendaba un tejedor - a dar todas las veces que me lo pida por el libro del susodicho y por el mío, y no pareciendo por el libro que yo tengo se a de dar por el libro del susodicho mercader, y si en ambos no pareciere se a de dar por solo su juramento».

¿Cuál fue la causa de que el mercader cediese un telar al maestro si debió disponer del aparejo productivo? En las ordenanzas gremiales está considerado como la herramienta fundamental para que el tejedor realizase su trabajo y, por tanto, debía contar con ella, sin concretar nada sobre su entera propiedad o en calidad de préstamo ${ }^{73}$. Conseguir un artificio propio era la aspiración de los maestros del arte. Hasta lograrlo muchos aceptaban un traspaso, más que nada al comienzo de una vida profesional, al no disponer de capital suficiente para

69 No hay demasiada analogía en el precio de los telares. He aquí unos valores del año 1649. Un telar de piñuela fue ajustado en 870 rls, como mínimo y 1.034 como máximo; el de damasco oscilaba entre $1720 \mathrm{rls}$ y $1956 \mathrm{rls}$, mientras el de terciopelo no bajaba de mil reales. AHPT. Protocolo 78, fol. 630, año 1649, Juan de Salcedo. Lo normal es que el mercader le cediera el dinero para la adquisición de un telar y lo recuperase descontando una cifra pequeña del valor de cada tela tejida. AHPT. Protocolo 780, fol. 92, año 1679, Cristóbal Ramírez

70 RoDrígueZ, J. y LÓPEZ, Carlos; «Modos de producción precapitalistas», Clases y conflictos sociales en la Historia. Madrid, 1977, p. 175.

71 Hamilton, Earl. J.: El tesoro americano y la revolución de los precios, 1501-1650. Barcelona, 1975 , p. 108 , indica que, a partir de 1652 , el premio de conversión quedo establecido en el cincuenta por ciento.

72 Los libros contables más utilizados por los toledanos son tres: manual, caja y borrador. Las funciones de ellos en GONZÁLEZ FERRANDO, J. M.; «Los libros de cuentas de la familia Ruiz, mercaderes banqueros de Medina del Campo (1551-1606)", I Congreso sobre Archivos Económicos de Entidades Privadas, (1983), pp. 23-45. Los mercaderes utilizaban los libros mayores, manuales, para anotar las deudas con las maestras hilanderas y tejedores, como se evidencia en el inventario realizado al escritorio del jurado Antonio de García Alonso. AHPT. Protocolo 3707, s/fol., año 1680, Gabriel de Morales. La ropa labrada se anotaba en un libro, que no parece ser otra cosa que un registro de existencias. Protocolo 425, fol. 81, año 1684-6, Eugenio de Piedrahita, inventario de Pedro de Recas.

73 Simón Zapata y Juan de Salinas daban trabajo a tejedores a los que, previamente, vendían el telar. AHPT. Protocolo 3643, fol. 40, año 1665, y núm 3539, fol. 511, año 1691, Diego de Soto y Nicolás López

Hispania, LXII/1, núm. 210 (2002) 65-112 
invertir en activos fijos. Otros se ponían bajo el patrocinio de un mercader por su incapacidad para acumular géneros, vender a crédito o disponer de dinero para comprar hilos ${ }^{74}$.

$\mathrm{La}$ abundancia de contratos suscritos entre tejedores y mercaderes en el periodo comprendido entre los años 1670 y 1682 permite sacar dos conclusiones. $\mathrm{El}$ incremento de escrituras entre las dos partes contratantes, en primer lugar, evidencia la existencia de un empobrecimiento entre los maestros. La pérdida de independencia no es, ni más ni menos, que una forma de hacer frente a la crisis. En segundo lugar, la abundancia de cesiones documentadas no tenían otra finalidad que asegurar la devolución de los telares y la seda en bruto que los mercaderes traspasaban. La inestabilidad económica del periodo comprendido entre 1680-1685 fomentó las suspicacias de los dueños de materia, que sospechaban podían ser víctimas de engaños. Para evitarlos utilizaron un instrumento legal, la obligación, donde quedó constancia de las cesiones ${ }^{75}$. Esa actitud contrasta con lo que habitualmente hicieron en épocas de euforia económica. Entonces dieron a los tejedores ciertos complementos para impedir que trabajasen con otro mercader, como era el pago del alquiler de la casa donde instalaban el telar ${ }^{76}$.

Las relaciones entre tejedores y mercaderes se mantuvieron inmersas en un sinfín de complejidades, con interrogantes muy heterogéneos, algunos todavía sin una respuesta concreta. Desconocemos, en ese sentido, cuál es el precio del trabajo. Los mercaderes, en su papel de oferentes de trabajo y dueños del capital, pretendieron maximizar los beneficios y para conseguir esa meta ajustaron al mínimo el coste de producción, más que nada en momentos de excedente de mano de obra. Los mercaderes anticiparon a los tejedores la materia y una cantidad en dinero, cuya recuperación efectuaban descontándoles pequeñas cantidades a la entrega de tejido confeccionado. La cantidad adelantada, por supuesto, no es lo suficientemente indicativa para saber el valor exacto del factor trabajo, aunque es de suponer que sería una cifra aproximada ${ }^{77}$.

${ }^{74}$ García SANZ, Mercaderes hacedores de paños en Segovia..., pp. 65-79.

75 La baja de la moneda de 1680 tendrá una incidencia muy negativa en las economías de los maestros sederos; tanto que muchos optaron por presentar quiebras. Otros eran encarcelados al no poder pagar las deudas contraidas. Un testimonio en AHPT. Protocolo 289, fol. 1359 y ss., año 1681, Eugenio de Valladolid.

76 AHPT. Protocolo 3780, fol. 191, año 1679, Cristóbal Ramírez. El mercader Juan Gálvez cedió unas casas, que alquilaba en el Arquillo de Santo Tomé, a dos maestros del arte con el compromiso de que trabajasen para él.

77 Una vara son 893,9 milímetros. En 1668 tejer una vara de terciopelo liso costaba 59 rls. La de damasco se pagaba a 33 rls vara; por hacerlo en damasco con follajes salía a $38 \mathrm{rls}$; tejer las pinuelas costó a 26 rls cada vara; el fondo ajado resultaba a $50 \mathrm{rls}$; el manto de lustre a 112 rls y las colonias a un real por vara. Conviene advertir que son datos aislados. AHPT. Protocolo 3489, fol. 84, año 1668, Sebastián López de la Cruz. Podía tejer un telar de raso algo más de 60 varas al mes; el de terciopelo negro alrededor de 18 varas; mientras que los de damasco urdían 76 varas. AHMT. Caja 2294, Relación de fábricas de seda y telares, año 1692.

Hispania, LXII/1, núm. 210 (2002) 65-112 


\section{UNA NUEVA FORMA DE INVERSIÓN: LA COMPAÑIÍA COMERCIAL}

En el mundo comercial toledano de los siglos XV y XVI fueron bastante numerosas las sociedades colectivas de tipo familiar y las conyugales. La constitución de las primeras se hizo por la adhesión de varios familiares y parientes, con un capital inaugural variables y una aportación diferente de cada socio, ejerciendo uno de ellos las funciones de administrador a cambio de recibir una parte mayor de las ganancias obtenidas, mientras los otros se mantenían ajenos a la operativa comercial ${ }^{78}$. Las compañías de tipo conyugal serían más exclusivas y las formaban el marido y la mujer. Si él fallecía los derechos se transmitían a los hijos en su condición de beneficiarios de la herencia, y la viuda se encargaba de representarlos en calidad de tutora en el caso de ser menores, mientras que el hijo mayor asumía la gestión de la herencia, si su capacitación lo permitía. Un ejemplo significativo fue la sociedad que establecieron Mariana Alonso de Martín Alonso y su marido Alonso de Paniagua, que era conyugal y su capital estaba constituido íntegramente con la dote de la mujer. Paniagua falleció y la viuda colocó al frente del negocio a uno de los hijos con el fin de evitar que esa parte de la herencia pudiera perderse. La mujer advertía en el documento que era la propietaria exclusiva del capital y renunciaba a ejercer las tareas de gestión por carecer de condiciones prácticas para ello: «ya que no tiene edad, ni inteligencia para comerciar, y es mucha la inteligencia de su hijo.... ${ }^{79}$.

Otra modalidad de participación asociativa fueron los depósitos o los préstamos con interés convenido o fijo. En esta línea hay que destacar, en primer lugar, el testimonio que transmite una obligación suscrita por Francisco González y compañía, que aceptaba, el año 1676, una cesión de 200 ducados a cambio de pagar al prestamista un interés fijo del cinco por ciento anual, sin ningún riesgo de pérdida o quiebra para él ${ }^{80}$. Otro segundo ejemplo lo aporta el préstamo que hizo Baltasar de Andrada a la compañía del mercader Marcos Díaz, por valor de 25.000 reales de plata y a recuperar tres años después en las mismas monedas del préstamo. En este caso no quedó constancia del tipo de interés al que se negoció la operación, pero es llamativo que Andrada, sin duda para obtener mayor rentabilidad al dinero entregado, exigiese que la devolución se hiciese en plata. En un caso extremo la aceptaría convertida en vellón, eso sí, ajustado su premio al 152\%. La compañía de los Vázquez de Dueñas, dos de los fabricantes más activos de la ciudad a partir de 1670 , es un modelo más a tener en cuenta. Ambos socios tomaron de diferentes personas importan-

${ }^{78}$ La modalidad aludida en BRAUDEL, Fernand: Civilización material, economía y capitalismo, siglos XV-XVIII. Madrid, 1984, vol. II, pp. 374-382. GómEZ MENOR, J. Carlos: Cristianos nuevos y mercaderes de Toledo, Toledo, 1979, en los cientos de documentos relacionados con el comercio toledano no cita ninguna sociedad similar a la aludida.

79 La compañía comenzó su andadura con un capital de 200.000 rls. AHPT. Protocolo 3788, fol. 896, 1679, Cristóbal Ramírez de Perales.

${ }^{80}$ AHPT. Protocolo 3786, fol. 22, 1676, Cristóbal Ramírez de Perales.

Hispania, LXII/1, núm. 210 (2002) 65-112 
tes sumas en depósito. Así, por ejemplo, de Juan Fernández de Madrid recibían 20.000 rls en plata bajo el compromiso de cancelar la deuda un año después y pagar al depositante un interés variable, que podía situarse entre un siete y nueve por ciento, en función de las ganancias que obtuviera él con el dinero ${ }^{81}$.

El sistema de compañías fue una práctica exclusiva de inversión para aquellos individuos que tenían disponible un capital y no querían arriesgar la totalidad de su patrimonio. La mayoría de los copartícipes, conviene destacarlo, eran conocedores de los entresijos del comercio al haber ejercido la profesión con anterioridad. Un buen número de estos inversores no quisieron figurar como co-titulares del negocio; de tal forma que en la razón social aparecía únicamente el nombre de su socio, que fue complementado con el abreviatura y Cía. Desde esa posición en la sombra buscaban pasar desapercibidos y unas ganancias que les permitieran detraer periódicamente una parte para poder vivir, lo que denominaron el «sustento de su casa y familia».

Las circunstancias económicas especiales del mundo económico toledano entre 1660 y 1695 facilitó el aumento de las compañías. Hasta tal extremo se desarrollaba esa práctica que en un período de treinta y cinco años se documentan varios centenares de sociedades, según queda reflejado parcialmente en el cuadro núm II. La cifra total de sociedades está simplificada al seleccionar sólo las que comerciaban con géneros de seda y su capital fundacional era igual o superior a 180.000 reales.

CUADRO II. Compañías sederas fundadas en Toledo entre 1660 y 1695

\begin{tabular}{|c|c|c|c|}
\hline NÚM. COMPAÑíAS & CAPITAL FUNDACIONAL & DURACIÓN & ACTIVIDAD \\
\hline 1 & 600.000 reales & 4 & Artículos seda \\
\hline 1 & 555.000 & 2 & seda y estameñas \\
\hline 1 & 500.000 & 3 & Seda \\
\hline 8 & $400.000-499.000$ & $\begin{array}{c}4 \text { máximo y } 1 \\
\text { mínimo }\end{array}$ & Seda \\
\hline 39 & $300.000-399.000$ & 4 & Seda \\
\hline 60 & $200.000-299.000$ & 4 & Seda y estameñas \\
\hline 71 & $180.000-199.000$ & 4 & " " \\
\hline
\end{tabular}

La andadura de cualquier asociación, en teoría, comenzaba con la redacción de una escritura pública, cuyas cláusulas no presentan diferencias ostensibles si se comparan con las de asociaciones análogas erigidas en otros puntos de la

${ }^{81}$ Los ejemplos podían multiplicarse considerablemente. Más referencias en los protocolos 387, fol. 429 y 3480, fol. 1028, Domingo Lorenzo y Sebastián López respectivamente, y en 3789, fol. 254, año 1680, Cristóbal Ramírez.

Hispania, LXII/1, núm. 210 (2002) 65-112 
geografía española ${ }^{82}$. Lo corriente fue que uno de los socios conociese bien el negocio por haber ejercido de mercader o factor con anterioridad. Con frecuencia, el socio que aportaba el dinero no quería asumir ningún cometido, por eso intervenía en un segundo plano. Adoptaba, además, un sentido de precaución, ya que al establecer la sociedad y colocar la frente de ella a un factor podía limitar la garantía única y exclusivamente al capital fundacional. Algo que no podía hacer al comerciar fuera de la sigla societaria, esto es, de forma unipersonal ${ }^{83}$. A primera vista, da la impresión que la compañía es una alternativa empresarial novedosa que apareció en el Toledo de la segunda mitad del Setecientos. No es así, ya que desde antiguo existieron asociaciones semejantes en el mundo comercial y pasan más inadvertidas por la simple razón de que los socios las iniciaban con un simple acuerdo verbal, sin la intervención de un escribano público que escribiese la minuta ${ }^{84}$.

La práctica societaria, en este mismo orden de cosas, no fue exclusiva a un determinado grupo de personas y la posibilidad de participación estuvo abierta a gentes de muy diversa extracción, aunque quienes más concurrían era antiguos mercaderes, tratantes, maestros del arte de la seda enriquecidos y algún que otro clérigo y burócrata ${ }^{85}$. Las sociedades presentaban señas de identidad muy similares entre sí, con ciertas variantes formales y estructurales entre las que se dedicaban a comerciar con artículos de la seda y aquellas otras que eran fundadas para realizar una actividad distinta ${ }^{86}$. Un signo de identidad general es la figura del factor. Este personaje ejercía en la tienda-almacén la inmensa mayoría de las operaciones, un local habitualmente alquilado que dispuso de un buen emplazamiento espacial al situarse, por lo general, en un barrio de mucho tránsito y paso. El triángulo más apropiado para ello iba desde la calle Ancha, Lencería y la Alcaná, con expansión hacia las Cuatro Calles e incluso

82 ÁNGUlo MORALES, Alberto: Del éxito en los negocios al fracaso del Consulado. La formación de la burguesía mercantil de Vitoria (1670-1840). Bilbao, 2000, pp. 219-244.

83 FERNÁNDEZ De PINEDO, Emiliano: Crecimiento económico y transformaciones sociales en el País Vasco, 1100-1850. Madrid, 1974, p. 61. También CASAdo Alonso, Hilario: Castilla y Europa. Comercio y mercaderes en los siglo XIV, XV y XVI. Burgos, 1995, resaltan la participación de nobles en el comercio

${ }^{84}$ Las uniones mercantiles mediante acuerdos orales fueron frecuentes, BASAS, Manuel: "Contratos de compañías mercantiles castellanas del siglo XVI», Revista de Derecho Mercantil, 70 (1960), pp. 375-412.

${ }^{85}$ Tanto Molas Ribalta, Pedro: La burguesía mercantil en la España del Antiguo Régimen. Madrid, 1985, p. 90, como GACTO HERNÁNDEZ, Enrique: Historia de la jurisdicción mercantil en España. Sevilla, 1971, estudian la disimilitud para distinguir a un tratante, un tendero y un mercader. SANTOS VAQUERO, Angel: «Vicente Díaz Benito: El mercader-fabricante más poderosos de Toledo en el siglo XVIII", Anales Toledanos, XXXVI (1998), pp. 115-131. WeIsser, Les marchand de Toléde..., pp. 223-4, estudió a los tratantes de Zocodover.

86 Esas uniones mercantiles abundaron en el mundo comercial, CARRASCO GonZÁlEZ, Comerciantes y casas... RÓDENAS VILLAR, Rafael: Vida cotidiana y negocio en la Segovia del Siglo de Oro. El mercader Juan de Cuéllar. Salamanca, 1990, pp. 107-9. VILLAR GARCÍA, María. Begoña: Los extranjeros en Málaga en el siglo XVIII. Córdoba, 1983, p. 156

Hispania, LXII/1, núm. 210 (2002) 65-112 
ciertas calles de la parroquia de san Ginés. Una de las cualidades más sobresalientes de factor era la experiencia, entre otras cosas porque de situar al frente del negocio a un inexperimentado podía llevarlo a la ruina.

$\mathrm{La}$ asociación mercantil de un capitalista con un gestor, formada por dos, tres o cuatro socios, era una unión bastante desigual, en la que el favorecido era quien ponía el dinero. El factor, por el contrario, debía asumir todas las competencias y obligaciones ${ }^{87}$. Tomaba las decisiones relativas a la gestión, sopesó los planes tácticos, llevó personalmente la contabilidad, planificó la distribución de los géneros y mandó a los mozos y arrieros a vender por las ferias ${ }^{88}$. El otro compañero, entretanto, mantendrá una postura expectante, caracterizada por su escasa responsabilidad, a la espera de recibir diariamente, o de manera mensual, una cantidad a cuenta de las ganancias que producía su capital. Hay casos en que aceptó un mayor compromiso como era vigilar el negocio al tener que ausentarse el factor para realizar un cobro o caer enfermo. Francisco de la Cruz Maestro colaboró, en una actitud infrecuente, con su factor Francisco de Bargas, ya que consintió hacerse cargo del negocio en el momento en que surgiera cualquier ausencia del factor, una enfermedad o un exceso de trabajo ${ }^{89}$. Por lo general, el capitalista exigió a su camarada que su gerencia fuese siempre positiva. El jurado Diego García de Olalla, al fundar una compañía que ubicaba en Sevilla para vender géneros de seda, paños y jerguillas elaboradas en Toledo, convino con sus dos factores, Francisco, su hermano, y con un tal Martín de Isunca, que obtuvieran un mínimo de ganancias, cuyo importe cifraba en la cantidad a recibir todos los meses ${ }^{90}$.

En contadas ocasiones se ocuparon directamente los factores de enviar mercaderías a Indias, al ser conveniente hacerlo contando con la experiencia de un consignatario o poderdante. Este personaje se encargaba del embarque de los géneros en Sevilla, de pagar los fletes y de efectuar los cobros al llegar la mercancía a su destino. Los capitanes de las naos también se encargaban de efectuar las operaciones mercantiles antedichas, unas veces en calidad de encomenderos, como socios del propietario de la mercancía o bajo otra modalidad de

87 LOBATO FrANCO, Isabel: «Reglamentación y práctica en las compañías mercantiles barcelonesas en la segunda mitad del siglo XVII», MARTínEZ SHAw, Carlos (editor): El Derecho y el mar en la España moderna. Granada, 1995, pp. 59-79.

${ }^{88}$ MARTínEZ GuJón, José: «La práctica del comercio por intermediario en el tráfico con las Indias durante el siglo XVI», Anuario de Derecho Histórico Español, XL, pp. 5-7. BASAS, Manuel: «El factor de negocios entre los mercaderes burgaleses en el siglo XVI», Boletín de la Institución Fernán González 148 (1959), pp. 742-745.

89 AHPT. Protocolo 446, fol. 11, año 1685, Diego López de los Cobos. Estar al margen de cualquier obligación fue algo que exigieron, en el momento de la constitución, algunos socios. El factor aceptó que "sonase siempre a su nombre y cabeza". Protocolo 232, fol. 979, año 1688, Nicolás López.

90 AHPT. Protocolo 232, fol. 1472, año 1687-90, Nicolás López. 
negociación mercantil ${ }^{91}$. Los artículos, en la mayor parte de los casos viajaron por cuenta y riesgo del expedidor, según las condiciones que figuraban en el poder otorgado por el propietario de los géneros ${ }^{92}$.

Una de las cualidades más reputadas de un factor era su eficacia, o lo que es igual, la suma de formación y experiencia, un compendio de cualidades denominadas «manejo y factoría». Un factor experimentado fue casi siempre un buen gestor, con condiciones para vender y comprar, dado que los retornos le servían para acopiar mayores ganancias. El traslado de géneros textiles por diferentes regiones lo completó con el regreso cargado de variadas mercancías, unas procedentes de Andalucía y otras del norte peninsular, añiles, azúcar, palo de Campeche, pescado, hierro y otros artículos exóticos, de amplia aceptación por los consumidores de su ciudad y pueblos de los alrededores ${ }^{93}$.

Al contrario de lo que parece, el apoderado gozó de escasa independencia y mantuvo limitada su actuación a las decisiones del capitalista, que disfrutaba de amplias facultades para suspender la actividad por cualquier motivo. Tal es así que podía despedirle al encontrar fallos en los libros contables, por equivocarse al efectuar el inventario o debido a la concesión de un aplazamiento de pago sin su autorización. La adopción de una actitud tan vigilante por parte del que ponía el dinero no tiene otra finalidad que la de coartar los intentos de desfalco de su empleado, bien con una actuación personal o con la complicidad de algún cliente ${ }^{94}$. Lo cierto y verdad es que la subordinación del factor hacia el capitalista era tan fuerte que implicó conductas inherentes a la privacidad, como el vivir en la casa del socio, recibir de él los alimentos, incluso los vestidos, o requerirle su beneplácito a la hora de casarse ${ }^{95}$, ya que si tomaba unilateral-

91 GARCIA FUENTES, Lutgardo: Los peruleros y el comercio de Sevilla con las Indias, 1580-1630. Sevilla, 1997, pp. 80-85. FERNÁNDEZ GONZÁLEZ, Fernando: Comerciantes vascos en Sevilla, 1650-1700. Bilbao, 2000, pp 61-63. El comerciante toledano Juan Becerril y Cía mantendrá en Sevilla a dos agentes, uno de ellos familiar del Santo Oficio. Benito Jiménez de Apodaca hizo lo propio y nombró a Nicolás Bucardi. AHPT. Protocolo 231, fol. 139 y 143, año 1679, Nicolás López y 3633, fol. 5 , año 1661, Martín de Villaseñor.

92 Datos sobre la red de intermediarios que actuaron en el comercio con Indias en BUSTOS, Manuel: Historia de Cádiz. Los siglos decisivos. Madrid, 1990, p. 69-70. VILA VILAR, Enriqueta: Los Corzo y los Mañara: Tipos y arquetipos del mercader con América. Sevilla, 1991, pp. 77-79.

${ }^{93}$ AHPT. Protocolo 3778, fol. 448, año 1667, Cristóbal Ramírez. La existencia de compañías especializadas en ciertos productos generó un complejo mundo de tratos y contratos muy especulativos. RAmos MEDINA, M. Dolores: Una familia de mercaderes en Madrid: Los Clementes. Una bistoria empresarial (1639-1679). Madrid, 2000, p. 58.

94 Una cláusula de la escritura fundacional para la asociación de Martín de Beizama y Leonardo de Boyra impedía a Leonardo fiar más de 150.000 rls durante los cuatro año de vigencia societaria. AHPT. Protocolo 187, fol. 322, año 1679, Eugenio de Valladolid.

95 ATIENZA HERNÁNDEZ, Ignacio: «Pater familia, señor y patrón: economía, clientelismo y patronato en el Antiguo régimen", en PASTOR, Reyna: Relaciones de poder, de producción y parentesco en la edad media y moderna. Madrid, 1990, pp. 411-458, considera que relaciones de esa naturaleza llevan implícito un apoyo sentimental y económico.

Hispania, LXII/1, núm. 210 (2002) 65-112 
mente la decisión cesaba la actividad societaria. Actuaba con él como si fuese un criado más.

No fue todo tan desventajoso para el apoderado; hubo opciones positiva, si bien fueron más contadas. La suerte podía favorecer, de manera inesperada, al factor, a costa, eso sí, de la muerte del capitalista. La viuda, todavía joven, aturdida frente a la desgracia, incapaz de administrar la herencia, veía en el factor la salvación y le vinculaba al negocio y a su vida mediante un nuevo matrimonio. En no pocos casos, aquel arreglo de conveniencia surgía de la necesidad de salvaguardar la dote de la viuda, o los bienes gananciales y proteger la paterna en el caso de que quedasen hijos menores del matrimonio anterior. El factor accedía al enlace para dejar de ser criado y ascender a patrón ${ }^{96}$. Entre los muchos casos documentados es expresivo el protagonizado por una tal Angela Moreno, viuda del mercader Pedro Gutiérrez de Canales, que contrajo matrimonio con Lucas López Picardo, su factor. Al morir éste, volvió a desposarse con otro mercader que hacia muy poco dejaba de ser factor, más joven que ella, llamado Juan Chico de Pedraza, al cual recurrió para evitar la ruina. Ella adujo que era incapaz de gestionar el productivo negocio que poseía y Chico de $\mathrm{Pe}$ draza no desestimó la ocasión. Por cierto, muy ventajosa al llevar la mujer al matrimonio 131.792 reales mientras él tenía $21.000 \mathrm{rls}^{97}$.

El tiempo de vigencia de las compañías es otra cuestión a examinar con cierto detalle. Las partes limitaron el tiempo de sus actuaciones a uno, tres o cuatro años, plazo casi siempre regulado en función de la naturaleza de la actividad. En todo caso, las compañías dedicadas al comercio de artículos seda mantuvieron un marco de referencia concreto que abarcó desde un mínimo de dos años a un máximo de seis, aunque lo usual era cuatro años —apéndice I-, mientras otras asociaciones finalizaban sus actividades como mucho al año y no pocas veces las suspendían antes de lo acordado. Las causas de una separación cubrían un arco heterogéneo. Podían sobrevenir por la muerte de uno de los socios, la acumulación de pérdidas en la gestión, al cambiar el factor de estado civil, abandonar la casa de su socio ${ }^{98}$, o no conseguir las ganancias suficientes, como mínimo la necesarias para conjugar los gastos fijos ${ }^{99}$. Algunos capitalistas

${ }^{66}$ AHPT. Protocolo 319, fol. 759, año 1669, Francisco de Segovia. Matrimonio entre Ana Rodríguez y Alonso de Funes.

97 La mujer moría en 1682 y a Chico de Pedraza le correspondieron unos gananciales de 867.816 mrs. AHPT. Protocolo 3538, fol. 681, Nicolás López. La endogamia que practicaron las familias de mercaderes toledanos es semejante a lo que observa para Valencia FRANCH BENAVENT, Ricardo: «Las relaciones matrimoniales de la burguesía mercantil valenciana dieciochesca», La burguesía española en la Edad Moderna, Valladolid, 1996, tomo I, pp. 783-94.

${ }_{98}$ LOBATO FranCO, Isabel: Compañias y negocios en la Cataluña preindustrial. Sevilla, 1995, p. 101, dice que la fórmula más aceptada es la disolución a la muerte del socio administrador.

99 Podía ocurrir que el factor fuese tentado por otro capitalista y abandonase a su socio. En ese caso, el que rompía la compañía no podía recuperar el capital, si es que puso alguna cantidad. Bernardino Beizama y Pedro Leonardo Boyra acordaron una fórmula intermedia que permitía al se- 
eran socios o participaban de varias compañías al mismo tiempo, con el fin de diversificar su riesgo.

El motivo más justificado para saldar una asociación era la muerte de uno de los participes. A tenor de lo que dice una cláusula de las contenida en las escrituras de constitución, nada más ocurrir el óbito debía interrumpirse la actividad comercial. Ahora bien, el cumplimiento era arbitrario, sobre todo si el capitalista era el que fenecía ${ }^{100}$. La decisión de continuar la tomaban los herederos y en casos así mostraron bastante reticencia a suspender un negocio, sobre todo si generaba jugosos beneficios ${ }^{101}$. La hija de Juan Segovia Urquizu, al morir su padre en 1677, mantuvo la empresa regentada por Francisco de Bazterrica y liquidó otros negocios, entre ellos una tienda de paños y otra de listonería, al ser poco sustanciosas sus ganancias en comparación con la rentabilidad de la compañía sedera. Tal es así que en seis ejercicios, con un capital de $300.000 \mathrm{rls}$, obtuvieron unas plusvalías del ochenta y cinco por ciento ${ }^{102}$. No es un caso único y hubo bastantes semejantes. Otros capitalistas tomaban mayores cautelas, aún conscientes de que una vez muertos los herederos podían incumplir su última voluntad. El caso de los hermanos Blas y Juan Gómez Gamero presenta las advertencias referidas y en un instrumento notarial dejaban expreso deseo ambos de que el negocio quedase interrumpido nada más fallecer uno de los dos ${ }^{103}$. La prosecución de las actividades a la muerte del administrador resultó más complicado, aunque hay ejemplos que ratifican la prolongación societaria. En ese sentido resulta ilustrativo el caso de un acuerdo firmado en 1697 entre un capitalista y los familiares de su factor, que contrataron un gestor a sueldo, por 30 rls diarios, para continuar el negocio hasta la fecha de prescripción ${ }^{104}$.

¿Qué hacían los factores al finalizar una asociación?. Las posturas que adoptaron resultaban muy heterogéneas; unos rompían totalmente con sus socios, otros establecieron nuevas alianzas, hubo algunos que cambiaron de profesión... La mayor parte de ellos comenzó una andadura independiente; eso sí, con la ayuda de su antiguo asociado. Los acuerdos en los que se traspasaban acti-

\footnotetext{
gundo, en calidad de factor, recuperar un tercio del capital al abandonar el negocio sin haber concluido su plazo. AHPT. Protocolo 193, fol. 116, año 1685, Eugenio de Valladolid.

100 Pedro Alonso Paniagua y Pedro Asenjo acordaron que el capitalista podía liquidar la sociedad al ausentarse el factor, pero en el caso de ocurrirle una desgracia tendrían que transcurrir seis meses para hacer una liquidación. Si el factor quedaba invalido, el socio podía sustituirle o poner al frente de la compañía una persona de su confianza y pagar el sueldo de las ganancias del gestor. AHPT. Protocolo, 3809, fol. 134, año 1683, Jerónimo Pérez.

${ }^{101}$ Los sucesores podían incorporarse a la compañía y hacerse cargo de los intereses que en ella tuviera el difunto, LOBATO, Las compañías..., p. 97, MARTíNEZ GIJÓN, La compañía..., pp. 71-7, PETIT, Jean: La compañia mercantil bajo el régimen de las Ordenanzas del Consulado de Bilbao, 1737-1829. Sevilla, 1979, pp. 34-8.

102 AHPT, Protocolo 3645, fol. 28, año 1679, Martín de Villaseñor

${ }^{103}$ AHPT. Protocolo 409, fol. 16, año 1674, Jerónimo Pérez de Arís.

104 AHPT. Protocolo 2396, fol. 47, año 1697, Pedro de Galdos
} 
vos y pasivos de compañías al termino de la asociación son bastante frecuentes entre los años 1665 y 1690 . En este periodo es normal que al poner fin las partes al negocio el factor se hiciese cargo de todo el capital, obligándose a pagar la participación de su socio por medio de unas cuotas aplazadas en el transcurso de varios años ${ }^{105}$. El regidor Juan Calderón de la Barca decidió liquidar una sociedad en 1681 y ofreció a su factor, Mateo García Ortega, el traspaso del neto patrimonial valorado en 377.500 rls. Calderón le concedió un aplazamiento de siete anualidades, a razón cada paga de algo más de cuarenta y cinco mil reales, sin cobrarle, según consta en la escritura, intereses por la cesión. Una gratuidad que debe ponerse en entredicho por varias razones. No encaja, en primer lugar, con el espíritu mercantil de un crédito tan cuantioso y, en segundo lugar, tampoco es lógico que una amortización tan prolongada estuviera exenta de réditos, cuando el espíritu de la asociación anterior fue conseguir la máxima plusvalía de un capital. Es un modelo altamente ventajoso para el factor, pero no armoniza con el espíritu de un hombre de negocios. Por tanto, resulta casi seguro que tales cesiones llevasen un interés implícito, enmarañado en múltiples componendas que hacían imperceptible los réditos y que existieron, sin duda. La escritura firmada por Francisco de Bazterrica y Juan de Segovia Urquizu, al deshacer una compañía, aporta algunas pistas al respecto. Francisco se quedó con los activos y pasivos, cuya valoración a precios de compra y valor de las deudas, sumaba trescientos mil reales. Segovia cobraría 50.000 rls cada año. En la escritura publica que hicieron ratificaban la inexistencia de un lucro oculto, lo cual se resalta con la ya consabida frase de hacerle «merced y buena obra» a su antiguo colaborador. Esas palabras quedaban en entredicho al inventariar los bienes que dejó Segovia. En los papeles se menciona la deuda en contra de Bazterrica y aparece un recibo con los intereses del crédito, cuyo importe perdonaba la heredera al deudor ${ }^{106}$.

La mayoría de los inversionistas establecieron una barrera temporal muy breve a sus uniones comerciales ${ }^{107}$. El plazo máximo acordado pocas veces superaba los cuatro año. Limitar el tiempo de vigencia tuvo sobradas ventajas para los socios, pues les permitía recuperar el capital a plazo fijo y poner fin a la responsabilidad solidaria que mantenían desde la constitución de la compañía. No obstante, un buen número de ellas volvían a renovarse al llegar la prescrip-

105 El gran perjudicado era el factor, hasta el punto que algunos se comprometieron a cobrar las deudas atrasadas sin ninguna compensación económica. AHPT. Protocolo 144, fol. 152, año 1650, Eugenio de Valladolid

${ }^{106}$ Los réditos se valoraban en 22.322 rls, AHPT. Protocolo 3788, fol. 830, año 1679, Martín de Villaseñor. La argumentación doctrinal en DeL VIGO, Aberlardo: Cambistas, mercaderes y banqueros en el siglo de oro español. Burgos, 1997, pp. 333 y 411-20. HeSPANIA, Antonio M.: «Cálculo financieto y cultura contable en el Antiguo Régimen», PETIT, Carlos: Dei ius mercatorum al derecho mercantil. Madrid, 1997, pp. 92-108.

107 PETIT, La compañía..., p. 23. El derecho castellano fijaba una temporalidad muy breve a estas asociaciones mercantiles. 
ción. En el momento de la disolución, el factor será el responsable de valorar los diferentes componentes patrimoniales, el capital inicial, el final, con la separación del activo y el pasivo, las pérdidas o ganancias, dejando constancia de todo en un registro o balance detallado ${ }^{108}$. En esos inventarios no suelen aparecer reflejados los elementos fabriles que poseyó la sociedad, esto es, el inmovilizado fijo, pero si figuran como deudas pendientes de cobro, a pagar por los maestros que utilizaban los telares. El socio, como se dijo, al producirse la disolución recuperaría los telares, en las misma condiciones que los dio y con idéntico valor, sin tener en cuenta ninguna disminución por efecto del desgaste ${ }^{109}$.

\section{BENEFICIOS Y PÉRDIDAS EN LA GESTIÓN MERCANTIL}

Los balances suelen aportar una información transcendental para observar la marcha, gestión y administración de la compañía, más al tener que realizar el factor, cómo muy poco, uno a fin de año para evaluar si hubo ganancias o minusvalías. En el trance de que estas últimas, junto con el pasivo, fuesen cuantiosas, se organizaba una insolvencia provisional, que en casos extremos podía derivar a definitiva, o introducir cambios en la gestión para que los acreedores concedieran un nuevo aplazamiento, a cuya situación se denominó «falta el crédito» ${ }^{110}$. Confeccionar el inventario fue una de las obligaciones del gestor y una vez realizado tenía que presentarlo a su socio para que diera el visto bueno. En el caso de existir un desacuerdo sobre la composición o el valor de su contenido, los componentes de una compañía aceptaban someterse al dictamen de los componedores o terceros. Para realizar esa operación, volvían a comprobar la mercancía, el precio de venta, su calidad e indagaban la veracidad de los activos y pasivo contabilizados, aunque su labor prioritaria consistía en aproximar las posturas discordantes y cerrar un acuerdo que satisficiera a las partes ${ }^{111}$. En los registros se anotaban las existencias, los elementos de fabrica-

\footnotetext{
${ }^{108}$ Ese manual era un diario y tenía el valor de soporte probatorio en caso de litigio. GONZÁLEZ FERRANDO, J. María: «De las formas de llevar cuenta y razón, según el licenciado Diego del Castillo, natural de Molina», Revista Española de Financiación y Contabilidad, XVII, 55 (1988, pp. 183-222. Una amplia bibliografía en otro artículo del mismo autor: «Bartolomé de Solorzano adelantado de la contabilidad aplicada en España», Revista Española de Financiación y Contabilidad, XX, 68 (1991), pp. 751-755.

109 AHPT. Protocolo 3528, fol. 295, año 1655, Nicolás López, inventario de María Verdugo, mujer de Yuste de la Fuente.

${ }^{110}$ Los mercaderes que perdían el crédito evitaban su encarcelamiento acogiéndose en las iglesias o conventos, en "lugar sagrado". Diego López Pereira, en 1669, se refugió en los agustinos recoletos para negociar en libertad el pago de sus deudas. Ofreció a los acreedores un adelanto inmediato por valor de los dos tercios, a entregar en mercancías, y la condonación del tercio restante. AHPT. Protocolo 410, fol. 45, año 1669, Jerónimo Pérez.

111 A la hora de valorar los avanços no se tenían en cuenta el precio de compra sino el de mercado —el denominado método Fifo-.
}

Hispania, LXII/1, núm. 210 (2002) 65-112 
ción, las obligaciones que adeudaban los maestros o maestras, así como los compromisos corrientes de los clientes, el activo circulante exigible, y los impagados, deudores de dudoso cobro, una partida denominada ditas. A la hora de valorar las ganancias, las deudas pendientes de cobro serán consideradas pérdidas potenciales y formaban un fondo común e indivisible hasta el momento de disolver la compañía. Los débitos morosos resultaban difíciles de recuperar, aun invirtiendo en la operación innumerables esfuerzos y dinero. Para lograrlo los acreedores utilizaron la cárcel como un medio de presión, medida poco convincente ya que los insolventes podían conseguir una cédula de pobreza y evitar el encierro. La solución óptima consistió en convenir un finiquito, aun a costa de condonar una parte del saldo y que quedase avalada la deuda por un fiador o garantizada por una hipoteca ${ }^{112}$.

Cuando el factor poseía amplios conocimientos sobre el comercio y una habilidad especial para la gestión resultaba fácil conseguir beneficios. Bastantes de ellos alcanzaron sobradamente la meta. Uno de los triunfadores paradigmáticos será Leonardo de Boyra que se hizo rico gracias a las habilidades innatas que poseyó para la actividad mercantil. Comenzaba a trabajar en la compañía de Bernardino de Beizama, el año 1685, aportando una participación de trece mil reales; al casarse con Teresa Isidora Serrano Gaitán, el año 1698, hizo inventario de su capital y ya ascendía a 164.581 reales líquidos, lo que supuso haber incrementado, en el espacio de trece años, la suma inicial un $1.260 \%{ }^{113}$.

Un factor con buena formación mercantil podían considerarse un activo valioso para asegurar copiosas ganancias ${ }^{114}$. El aprendizaje de la tarea ejecutiva, la manera de gestionar, incluso los procedimientos utilizados para vender, serían hábitos adquiridos en un largo proceso de adiestramiento directo, observando la gestión que, día a día, realizaba un buen maestro ${ }^{115}$. Por tal circunstancia, algunos mercaderes contrataron a un experimentado factor para el aprendizaje de su hijos. Los encomendó para un rígido adiestramiento en el proceloso mundo del comercio, sin privilegios, en una posición parecida a la que disfrutaban otros criados. De esos factores se esperaban muchas cosas, aunque la principal era que facultasen a sus pupilos para cambiar decisiones con el mínimo coste de oportunidad. Un tal Diego Dávila Serrano tuvo muy en cuenta ese principio al fundar en 1677 una compañía comercial y poner al frente de ella a su hijo, un menor de veinticinco años, emancipado en el momento y carente de

112 Isabel Quijada escondió sus bienes y solicitó un privilegio de pobreza, con el que pensaba eludir la deuda que mantenía con la compañía de Manuel Díaz Gutiérrez. No tuvo éxito la treta y acabó en la cárcel. AHPT. Protocolo 3633, fol. 232, año 1661, Martín de Villaseñor.

113 La distribución fue la siguiente: mercaderías, $114.336 \mathrm{rls}$, deudas $74.395 \mathrm{rls}$, efectivo 11.702 rls y pasivo 35.932 rls. AHPT. Protocolo 3737, fol. 96, años 1697-99, José Martínez de Reluz.

114 Carrasco GonZález, Comerciantes y casas..., p. 44, muestra los pasos a seguir para conseguir una buena capacitación para el oficio.

115 BUTEL, Paul: Les dynasties bordelaises, de Colbert à Chaban. Paris, 1991, pp. 372-373, considera que los viajes daban un aprendizaje completario y sólido a la formación de un gestor. 
toda experiencia. Su falta de destreza sería rápidamente advertida por el padre, así que le forzaba a adiestrarse con un aprendizaje práctico al lado de un asistente eficiente y competente. Le transmitía conocimientos suficientes para atender la tienda, en la redacción de los apuntes contables, en la inspección de los libros, le asesoró para adquirir y vender de forma ventajosa y le dio suficientes instrumentos para que los acuerdos con los maestros tejedores fuesen ventajosos para él. Una lección nada gratuita, por supuesto, al quedar evaluado su salario en un quinto de las ganancias obtenidas cada año ${ }^{116}$.

Conviene no olvidar que la finalidad prioritaria en todo negocio eran las ganancias y cuanto más considerables, mejor. Jugosas fueron las generadas por algunas compañías toledanas que traficaban con sedas, sobre todo para aquellas que funcionaban con anterioridad a 1680, por fijar una fecha límite, al ser años en los que las posibilidades de enriquecimiento parece fáciles. Así lo testifican los registros conservados entre los protocolos notariales. Aún siendo muy completos carecen de ciertos indicativos necesarios a la hora de calcular lo que ahora se conoce como tasa de rentabilidad; o lo que es igual, averiguar si las ganancias obtenidas remuneraron adecuadamente el capital y el riesgo asumido. Tanto los acuerdos de suspensión de compañías como sus balances son documentos precisos para advertir el valor de la retribución que recibieron los capitales. A la hora de desvelar esa incógnita es ineludible utilizar dos datos: los beneficios brutos y el valor total del activo ${ }^{117}$. Así y todo, el resultado de la operación puede llevar a cierta imprecisión, a causa de que algunos socios recibieron unas remuneraciones de dificultosa estimación, considerados por ellos como gastos personales y domésticos, que no descontaban de los beneficios ante la imprecisión que tenía de cuales eran bienes personales y cuales los societarios.

La rentabilidad de las sociedades abarcó un espectro variable. Mientras unas obtenían un insignificante tres por ciento anual, otras llegaron al veinticinco y mayores porcentajes. En un arco tan versátil hubo ciertos casos llamativos; la que regentó Juan de Villavieja es bastante elocuente, al conseguir en más de una docena de años un $16 \%$ de rentabilidad media ${ }^{118}$. Los beneficios de la compañía de Julián Castaños y Francisco de Velasco y Blas Duro, vigente entre los años 1673 y 1676, reproducen la premisa más sustanciosa al situarse en el $21,93 \%$, sobre un capital fundacional de $200.000 \mathrm{rls}^{119}$. Joaquín Masip y José Pulido, este último en calidad de factor, ganaron nada más y nada menos que 13.000 rls en un año, con un capital de 40.000 reales, cuyo fin fue comprar seda sin elaborar ${ }^{120}$. Las plusvalías de la compañía de Teresa de Huerta son

\footnotetext{
116 AHPT. Protocolo 287, fol. 878, Martín de Villaseñor

117 Es la relación entre la obtención de un determinado beneficio y el esfuerzo realizado para conseguirlo. Calcular la rentabilidad del negocio es muy problemático, ya que es imprescindible conocer los beneficios brutos, los intereses de las deudas con terceros y el valor de los fondos propios

118 AHPT. Protocolo 176, fol. 249, año 1672, Eugenio de Valladolid.

119 AHPT. Protocolo 327, año 1677, fol. 379, Diego Fernández Ramila

120 AHPT. Protocolo 3638, fol. 311, año 1668, Martín de Villaseñor.
} 
más impresionantes al situarse en un $168 \%$, en los tres años que duró su asociación. Detrás de esa cifra de beneficios existió un problema, de enorme magnitud, que pudo desencadenar una aparatosa quiebra, ya que los bienes y derechos de la sociedad eran inferiores en casi un ochenta por ciento en relación con las obligaciones contraidas ${ }^{121}$. Menores fueron las ganancias logradas Alonso de Funes y sus factores, Andrés Rodríguez y Miguel de Zubieta, que obtenían sólo un $16,5 \%$ anual, entre $1672-1676^{122}$.

Las causas de las pérdidas podían sobrevenir por contrariedades muy diversas. En ocasiones, las producirían ventas insuficientemente garantizadas; en otras, son los mismos socios quienes las generan al exigir a sus factores el traspaso de cifras semanales muy altas. Les obligaron, según queda reflejado en las escrituras de constitución, a darles una asignación mensual muy alta, sin tener en cuenta que su inversión difícilmente podía generar esos beneficios. Los socios que ponían el capital aspiraban a hacer frente con holgura a un montón de necesidades personales y domésticas, entre ellas el mantenimiento de su familia, del factor, o hacer frente a los gastos fijos, salarios de los mozos que ayudaban a la administración, alquiler de la tienda, los impuestos y un largo etcétera. En el caso de que los gastos de explotación fuesen considerables, el factor optaba por incrementar las ventas a fin de armonizar las ganancias con las necesidades y, en casos extremos, decidía tomar del activo real la cantidad necesaria, con la consiguiente reducción del capital.

En lo que respecta a las pérdidas hubo algunas sintomáticas. La compañía de Catalina Gutiérrez de Saavedra, viuda de Pedro Jiménez de Mayorga, sobre un capital de 410.000 rls, perdió en tres años 93.416 rls, lo que suponían un $22 \%$ sobre los recursos propios. El percance hay que achacarlo a la actitud de la viuda, que detraía todos los meses una suma considerable para sus necesidades domésticas, muy por encima de los rendimientos del negocio. Fabiana González, viuda de Juan de Campoverde personalizó un caso muy parecido. En 1681 fundó una compañía con un capital de 220.000 rls y pasados tres años de actividad asumió pérdidas por valor de $66.000 \mathrm{rls}$, o lo que es igual un $30 \%$ del fondo económico. Motivó la minusvalía al exigir al factor que realizase todas las venta al contado, una decisión que redujo bastante la posibilidad de hacer rentable la inversión ${ }^{123}$. Las pérdidas que tuvieron José Vázquez y Tomás Díaz fueron de menor consideración, al importar $9.306 \mathrm{rls}$, sobre un fondo inicial valorado en 476.285 reales $^{124}$

El objetivo de los factores, en definitiva, era conseguir una alta rentabilidad del capital y, a modo complementario, mantener los niveles del exigible en

${ }^{121}$ AHPT. Protocolo.232, fol. 966, año 1687-90, Nicolás López. Denominada «distancia a la quiebra» o ratio de garantía estructural que, en este caso en concreto, representó el 0,84\%.

${ }_{122}$ AHPT. Protocolo 172, fol. 618, año 1672, Eugenio de Valladolid

${ }_{123}$ AHPT. Protocolo 3436, fol. 1320. Año 1681. Protocolo 3538, fol. 30, año 1681, Nicolás López de la Cruz.

${ }^{124}$ AHPT. Protocolo 3633, fol. 1081, año 1661, Martín de Villaseñor 
cifras de poca consideración, algo de dificultosa consecución si se tiene en cuenta que los pagos aplazados eran una práctica habitual en los negocios. Aparte, los gestores debieron ajustar los costes de los factores de producción, los salarios de las maestras, incluso desarrollaron una gestión cautelosa basada en el triángulo formado por las siguientes premisas: muchas ventas al contado, pocas a crédito y posponiendo el vencimiento de los pagos para contar con liquidez ${ }^{125}$.

\section{MOROSIDAD Y SOLVENCIA DE LAS COMPAÑÍAS}

Los primeros pasos de una relación comercial perdurable comenzaban al establecer, comprador y vendedor, el límite de su línea de crédito, o lo que es igual, al fijar el máximo de los pagos diferidos. El acreedor abría una cuenta en su libro borrador siguiendo esta disposición; en la parte superior de una de las hojas escribía el nombre del deudor; un poco más abajo, en la hoja de la izquierda, anotaban los apuntes del cargo, el debe, reseñados de forma escueta, indicando la cantidad de género entregado al cliente, su valor y la fecha en que se hizo. La hoja alterna correspondía a la data y allí se contabilizarían las entregas que el acreedor recibió a cuenta, bien en dinero, vales, letras o bien en mercancías. La operativa de las anotaciones es bastante simple, sistema de cargo y data, por desconocer la mayoría de los mercaderes la partida doble.

En el caso de que el comerciante tuviera un patrimonio limitado, lo frecuente es que exigieran a sus clientes los pagos al contado, porque así disponía de efectivo para vivir y liquidaba las deudas a sus proveedores sin sobrepasar los plazos señalados ${ }^{126}$. Las ventas aplazadas comportaban un considerable riesgo económico, y uno de los más explícitos al enjuiciar la buena gestión comercial, debido a lo imprevisibles que eran los resultados de una venta al fiado. Los efectos de cobro, obligaciones y letras ${ }^{127}$, impagados a su vencimiento, comportaban unos gastos complementarios a la hora de recuperarlos, como eran el desplazamiento hasta el lugar donde estaba afincado el deudor, las minutas de procuradores y las costas relativas a la instrucción de un expediente judicial. En resumidas cuentas, esas cantidades fueron difíciles de recuperar en su totalidad, ni mediante los embargos ni con la venta de los bienes. El primer paso que debía realizar un acreedor para recobrar de un cliente moroso la cantidad impagada fue extender un poder a favor de una persona de su confianza o acudir el propio mercader a resolver la situación.

\footnotetext{
125 A la demora de pago de una obligación o letra, pasado el vencimiento, se denomina días de corridos y solía concederse un máximo de veinte días. AHPT. Protocolo 355, fol. 193, años 167377. José Martínez.

${ }^{126}$ Ahora se mide mediante un índice llamado límite de solvencia, que es la relación existente entre el capital y el pasivo exigible. cindad.

${ }^{127}$ Las obligaciones permiten identificar a los consumidores de la mercancía y localizar su ve-
} 
Aunque la solvencia de una compañía se refleja en los recursos propios disponibles para hacer frente al pasivo, los acreedores tenían en cuenta circunstancias adicional, en especial que los clientes practicasen una gestión transparente. En ese sentido, requirían informes sobre la marcha del negocio y sobre el comportamiento del mercader en la vida diaria ${ }^{128}$. Determinadas reglamentaciones jurídicas permitieron a los componentes de las compañías eludir el embargo de sus bienes patrimoniales y una de las operaciones más significativa para lograrlo consistía en delimitar únicamente la responsabilidad al capital de la sociedad comanditaria. Tal condición debía establecerse en la carta fundacional, porque de no hacerlo así el antiguo derecho castellano consideraba que los componentes de una asociación mercantil debían hacer frente, sin ningún límite y con todos sus bienes, a las obligaciones que contrajesen ${ }^{129}$. La fórmula notarial empleada para esa salvaguarda era la siguiente: «Iten que la dicha doña Francisca no a de quedar obligada ni se obliga a cosa alguna de la dicha compañía ni a pagar las deudas della más de tan solamente hasta la cantidad de su puesto y que jamas a de arriesgar ni perder mas de los dichos cuarenta y cuatro mil reales que pone por caudal y puesto en la dicha compañía, porque así es pacto de este contrato...»130. El ordenamiento legislativo lo siguió al pie de la letra Juan Becerril, al igual que hicieron otros muchos socios, en el momento de fundar una compañía mercantil. Becerril concretó su responsabilidad en medio millón de reales, que era su aportación económica, y advertía que el resto de su patrimonio ni era embargable ni cubría las deudas de la compañía ${ }^{131}$.

Disfrutar de la consideración de desahogo económico, algo que en el lenguaje coloquial aparece designado "pundonor», fue uno de los deseos al que aspiraba todo mercader ${ }^{132}$. Aquel que buscó dar una imagen de prosperidad y riqueza, lo lograba si tenía un almacén bien surtido y expedía géneros a las ferias más concurridas de ambas Mesetas, Extremadura y Andalucía, bien por medio de factores que operaban en su nombre, mediante tratantes que trabajaban al fiado, a comisión o aprovechando la diferencia entre el precio de compra y el de venta. El renombre se agrandaba si contaba con mozos, arrieros asalariados y un encargado, en calidad de responsable del género, que actuaba en calidad de tomador de las obligaciones o recibía el dinero de los pagos al contado.

En los siglos XVI y XVII vender al fiado fue una práctica común y ampliamente generalizada. La compañía comercial o el mercader individual no

\footnotetext{
128 CARRASCO GONZALEZ, Comerciantes $y$ casas..., p. 53

129 MARTínez Gijón: La compañía mercantil ..., 1979, pp. 200-3, analiza con amplitud el papel desempañado por los socios y sus aportaciones. Una aportación complementaria en OLIVENCIA, Manuel: «Sobre la Historia de la compañía mercantil», Revista de Derecho Mercantil, núm 160 (1981), pp. 313-324.

130 AHPT. Protocolo 3524, fol. 696, años 1657-8, Nicolás López

131 AHPT. Protocolo 3493, fol. 634-659, año 1677, Sebastián López de la Cruz

132 Para «comerciar con pundonor» Pedro Lázaro recibió de su madre 800 ducados, AHPT. Protocolo 3635, fol. 491, año 1672, Nicolás López.
} 
podían exigir que todas las ventas fuesen al contador, pues al cerrar el crédito limitaba el tráfico mercantil y las ganancias. No era fácil crear una línea crediticia basada en la confianza y la honradez, al ser un don escaso, muchos más en momentos de crisis. La solvencia de un cliente era inspeccionada de forma cuidadosa por su proveedor. De parecerle escasa, el deudor debían afianzar su obligación de pago con un avalista o hipotecando algunos derechos de propiedad. En esas escrituras no suelen figuran referencias sobre el cobro de intereses por el aplazamiento pero, con toda certeza, éstos fueron incluidos de manera encubierta, en función del plazo de la moratoria y de la seguridad entre vendedor y adquirente.

De algún modo, las palabras anteriores justifican el porqué las uniones mercantiles que daban sus primeros paso con sólo dinero en efectivo eran escasas. El capital de la inmensa mayoría de las compañías lo formaban tres elementos: poco dinero, muchas deudas y algunas mercaderías. Los inventarios post mortem y los balances de constitución de las sociedades permiten analizar la composición patrimonial de lo que, bajo una designación genérica, se denominaba puesto y caudal, o lo que es igual, el capital fundacional. En su composición no aparecen nunca reflejados los activos inmovilizados; hay una razón para que así fuese: la escasez y el alto coste del espacio comercial en una calle concurrida. Por ello, la inmensa mayoría de las uniones mercantiles utilizaron locales alquilados para instalar las tiendas. Claro, hubo excepciones y una de ella la protagonizaba Fabiana González, al fundar una sociedad a la que aportó una tienda y un almacén, aunque prefirió no valorar ambos componentes como patrimonio societario. Dejó de percibir el alquiler y exigió a su factor que la ubicación del negocio siempre permaneciese en el mismo sitio ${ }^{133}$.

La postura conservadora adoptada por muchos participes al asumir riesgos es otra actitud comercial que debe resaltarse, lo cual es fácil de comprender cuando se observa la insignificancia del pasivo; una postura, sin duda, con sus ventajas e inconvenientes. Era más principal el que limitaba el acopio de beneficios. Ahora bien, la manera aplicar el método a la gestión fue bastante divergentes. Bernardino de Beizama, al igual que hicieron otros mercaderes, mantuvo durante años inflexible esa operativa. Tal es así que en un balance elaborado el año 1672 su pasivo ascendía a un $7 \%$, mientras que el activo se distribuía en un $62 \%$ para mercaderías y el restante $28 \%$ lo constituían las partidas de activo exigible. Diametralmente opuestos serían los principios mercantiles que establecieron Timoteo Ferrer y un tal Andrés Fernández de Robles, al utilizar la financiación de terceros en el desarrollo de su negocio. El capital de los socios ascendía a $150.000 \mathrm{rls}$, mientras que el pasivo sumaba $153.422 \mathrm{rls}$, el $103 \%$ de

133 García BAQUERO GonZÁlez, Antonio: Cádiz y el Atlántico (1717-1778). El comercio colonial español bajo el monopolio gaditano. Sevilla, 1976, p. 432, ratifica que las compañías comerciales gaditanas usaban de esa prestación

Hispania, LXII/1, núm. 210 (2002) 65-112 
los fondos propios ${ }^{134}$. Entre ambos casos tan extremos existieron posiciones intermedias. Una es la que ilustra Juan Mateo del Rincón, depositario de pruebas del Santo Oficio y continuamente metido en los negocios de la seda a través de compañías. Moría el año 1696 y su patrimonio societario quedó valorado en la cifra de $435.848 \mathrm{rls}$, mientras que el pasivo sumaba $113.139 \mathrm{rls}$, lo que venía a representar el $26 \%$ de la masa patrimonial. La distribución del capital fundacional fue la siguiente: un diez por ciento correspondía a materias primas, un ocho por ciento a los telares en manos de los tejedores, un cuarenta y cinco por ciento valían las mercaderías que tenía en el almacén y el restante treinta y siete por ciento estaba representado por las deudas a su favor ${ }^{135}$.En definitiva, conviene resaltar que las compañías toledanas poseyeron un exceso de recursos propios y, en contraposición, un insignificante porcentaje de endeudamiento; un síntomas que los proveedores valoraban de forma positiva. Y es que un pasivo poco abultado limitaba los riesgo a una quiebra, aunque los costes de los flujos monetarios corrientes aumentaban por la inactividad del capital ${ }^{136}$.

Por otro lado, la acumulación de deudas impagadas al vencimiento producía una falta de liquidez y quedaban casi suspendidos los circuitos de intercambios de una compañía, ante lo problemático que resultó recuperar los instrumentos de pago impagados de forma rápida. Para lograrlo, los acreedores debían buscar un procurador que instruyese un expediente judicial. El juez, una vez instruido el proceso, podía poner en la cárcel al moroso hasta que liquidase la deuda o dejarle en libertad cuando disponía de un fiador que garantizase la liquidación. No resultaba infrecuente que el requerimiento procesal quedase invalidado ante un débito insuficientemente documentado. De ser así, la causa estaba perdida y con ella las expectativas de cobro. Para evitar el fracaso a la hora de efectuar una reclamación la obligación notarial suscrita por deudor y acreedor o una letra aceptada y protestada eran un excelente testimonio del impago. En el caso de no existir esa formalidad documental, existía una posibilidad más y consistía en mostrar a la justicia el libro diario donde estaba el apunte contable que originó el compromiso. Seguir un procedimiento distinto resultó ineficaz, puesto que cualquier otro requerimiento sería rechazado por el juez. Que era así y no de otro manera lo sabía muy bien Juan de Salinas Garibay Veitia cuando exigió el pago de una deuda a los herederos del inquisidor Juan Chacón Narváez, en 1678. Desde varios años atrás mantenía una deuda con él y una primera formalidad que siguió para recobrarla fue mostrar la cuenta abierta en sus libros a los albaceas y al juez. Salinas escribió en su día el siguiente apunte contable: «por una pieça de tafetán del reino de Grana-

${ }_{134}$ AHPT. Protocolo 288, fol. 755, año 1676, Martín de Villaseñor

135 AHPT. Protocolo 3603, fol. 584, 1651, Alonso Sánchez de Mora.

136 Carrasco GonZález, Comerciantes y casas..., p. 56, dice que el crédito de un mercader podía perderse por el impago de una letra de cambio aceptada, incluso por rumores y un mal entendido. Obviamente, la pérdida de confianza podía desencadenar una quiebra. 
da; rosco musco para librea y otra pieza de anafalla negra, más 900 rls que le di para gastar y comprar cebada, porque no tenía ni blanca» ${ }^{137}$.

A la hora de ajustar deudas entre mercaderes o compañías uno de los arquetipos predominante consistió en liquidar los saldos por medio de compensaciones, materias primas y productos transformados, vales, letras y obligaciones. Ese cierre de cuentas solía efectuarse en lugares y fechas concretas, casi siempre coincidiendo con ferias acreditadas, como la de Jadraque, Zafra, Guadalupe, Mérida, Toledo o Valladolid ${ }^{138}$. La compensación del saldo deudor por un vale o una letra debió provocar problemas de liquidez a más de un tomador, mucho más gravoso cuando el vencimiento se difería varios meses ya que impedía realizar el ciclo de rotación ${ }^{139}$. La carencia de efectivo debió arreglarse con la negociación de un anticipo que concedía otro mercader, que asumía la función de prestamista. Los derechos pendientes de cobro se cedían al prestamista como aval del dinero adelantado; para dar mayor garantía a la devolución un escribano extendía un documento donde constaba la cantidad entregada por el endosante, el plazo de devolución y la garantía o aval que aseguraba la recuperación del principal ${ }^{140}$. Con cierta reiteración se puede comprobar que los prestamistas exigían esas liquidaciones en oro o plata, aunque la cesión inicial se hiciera en moneda de vellón ${ }^{141}$. Así se hizo porque la conversión llevaba un premio que incrementaba los beneficios ${ }^{142}$.

La verdad es que pocos mecanismos comerciales tuvieron la categoría de gratuitos. La compensación de deudas o cualquier otro adelanto implicaba un coste para el beneficiario y un lucro para el prestamista. Hallar evidencias escritas en relación con la existencia de los réditos es cuestión de suerte. En éste caso un memorial del mercader Domingo Rodríguez aporta un detalle de considerable valor testimonial. El mercader confesaba que recibió un préstamo de una tal Mónica Sánchez, de los llamados de buena obra, por valor de 11.200 reales, de los cuales diez mil reales correspondían al principal y los mil doscien-

137 AHPT. Protocolo, 328, fol. 201, 1678, Diego Fernández.

138 En mayo se celebraba la feria de Trujillo y era una de las escogida para efectuar pagos, o la de Guadalupe que empezaba el día ocho de septiembre. La de Medellín y Valladolid, celebradas el día de San Andrés, o en Madrid, a final de año, servían para cerrar las cuentas AHPT. Protocolos 328, fol. 145, 1678, Diego Fernández Ramila, y 3866, fol. 202, 1696-7, Juan Fernández Hocos.

139 Aguilera Barchet MAdRd, Bruno: Historia de la letra de cambio en España. Madrid, 1988, hace un análisis exhaustivo sobre la letra de cambio.

${ }^{140}$ Los vales se semejaban a los actuales pagarés. Por este instrumento crediticio, el deudor se comprometía a pagar a su acreedor una cifra de dinero en el lugar y en el plazo concertado.

141 Un caso significativo en AHPT. Protocolo 230, fol. 857, años 1661-2, Nicolás López de la Cruz , préstamo de María de la Parra a la viuda e hijo del jurado Diego Fernández de la Reguera.

142 Esos préstamos, con cierto énfasis, resaltan su concesión "por hacerle bien y buena obra». Un prestamista muy activo fue Francisco Sanz Tenorio, regidor de Toledo. AHPT. Protocolo, 280, fol. 1364, 1672, Martín de Villaseñor. Francisco Alzamora recibió de él un préstamo por valor de 28.276 rls. a devolver en doblones de oro.

Hispania, LXII/1, núm. 210 (2002) 65-112 
tos reales restante eran los intereses ${ }^{143}$. La maraña de sutilezas semánticas utilizada en los documentos de obligación dificultan comprobar que los créditos fueron gratuitos. Tan convincente como el anterior testimonio es otro hallado en la escritura de disolución extendida entre Ambrosio Sánchez y Juan Díaz de Lizana. Éste optó por quedarse con «el puesto y caudal», cuyo valor eran $100.000 \mathrm{rls}$, comprometiéndose a pagar a Ambrosio la deuda en tres años y darle otros $16.954 \mathrm{rls}$, que correspondían a un interés del 5,6\% anual.

La concesión de pequeños préstamos a artesanos y comerciantes, a tipos de interés no muy altos, así como cambios que no eran usureros tuvieron una sobresaliente función en las actividades mercantiles ${ }^{144}$. Operaciones de esas características las practicaron el regidor Juan Calderón de la Barca, el caballero de la Orden de Santiago Francisco Sanz Tenorio o el jurado Juan Vázquez de Dueñas ${ }^{145}$, además de un amplio grupo de personas de menor significación social. Los receptores del dinero serán maestros artesanos y pequeños mercaderes que lo necesitaban para efectuar una compra específica, que cancelaban la deuda al vender el producto. Son, en perjuicio de los que afirman las partes, empréstitos onerosos, de interés variable, a un tipo que pudo oscilar entre el 5 y 10 por ciento, cuyos réditos se rebajaban en el momento de recibir el nominal. El deudor garantizó, a modo de caución, la posterior devolución del préstamo con la cesión de ciertas deudas que a él le debían.

El comportamiento de Pedro Carrasco Martín o Juan de Campoverde, dos importantes mercaderes de seda, seguía pautas semejantes a la hora de cobrar los géneros textiles que entregaban a mercaderes de Bergara, que había venido al centro peninsular a traer productos metalúrgicos hasta Mora y volvían a su tierra con textiles. Liquidaban los géneros a sus proveedores toledanos entregándoles las obligaciones suscritas por sus clientes morachos ${ }^{146}$.

Aparte del grupo, bien es cierto, poco numeroso, de los financieros existió otro que participaban en operaciones crediticias en un ámbito de consumo más doméstico ${ }^{147}$. Eran individuos que dejaban a los mercaderes su dinero en depó-

143 AHPT. Protocolo 3740, fol. 111, 1666, Diego Sánchez

${ }_{144}$ Negocios especulativos similares en MAIXE AltÉs, J. Carle: Comercio y banca en la Cataluña del siglo XVIII. La compañia Bensi y Merizano de Barcelona, 1724-1750. La Coruña, 1994, pp. 188223 y Ramos Medina, Una familia..., p. 107.

145 Juan Calderón entregó al comerciante Pedro de la Plaza la suma de 100.900 rls, sin indicar el valor de su beneficio. AHPT. Protocolo, 3389, fol. 233, 1669, Diego Bolante. Cristóbal de Balmaseda, que administró las propiedades de varios conventos, entre ellos la de El Escorial, facilitó dinero a Juan de Segovia y Francisco Villalba, sin fijar vencimiento ni el interés. AHPT. Protocolo 275, fol. 623, 1668, Martín de Villaseñor.

${ }_{146}$ AHPT. Protocolo 3530, fol. 4449, protocolo 3536, fol. 175, protocolo 3532, fols. 224 y 334.

147 GómeZ Alvarez, Ubaldo: «Obligaciones y censos: dos instrumentos de endeudamiento en el obispado de Asturias». Actas de las I Jornadas de Metodología Aplicada a las Ciencias Históricas, Historia Moderna, Santiago, 1979, p. 383. Las pautas sobre el papel de la demanda y el desarrollo de los procesos productivos en TORRAS, Jaime y YUN CASALILLA, Bartolomé (eds); Consumo, condiciones de vida y comercialización. Avila, 1999, pp. 9-23.

Hispania, LXII/1, núm. 210 (2002) 65-112 
sito, por un plazo fijado de antemano, cuya cesión quedaba escriturada en un simple papel, sin pasar ante un fedatario, para que lo invirtiese, a cambio de un interés y sin asumir el depositante ningún riesgo ${ }^{148}$.

\section{CONCLUSIONES}

Por último, a modo de epílogo, dos reflexiones finales. La primera es la propuesta que hizo Sancho de Moncada para establecer un plantío de moreras que fomentase la sericultura y la producción autóctona de sericina, como uno de los fundamentos esenciales para mantener el arte de la seda. Por determinadas circunstancias, el aumento del precio la seda, el control monopolístico al que estuvo sometida su distribución, la competencia de los textiles extranjeros, el abandono de la ciudad por numerosos maestros..., el número de telares descendió en el transcurso del siglo XVII. Los artesanos dejaron de fabricar por su cuenta y se pusieron bajo el patrocinio de un mercader; que les dejaba la seda, les entregó un telar y recogió los tejidos una vez elaborado. Algunos se denominaban fabricantes al intervenir en todo el proceso de producción. Junto con otro comerciantes utilizaron a los tejedores establecidos en localidades rurales para fabricar a menor coste que la confección hecha en la ciudad, sin tener en cuenta las normativas de calidad.

Las circunstancias económicas poco favorables para el comercio, fuerte inflación y sucesivas devaluaciones, constriñeron la práctica personal del oficio y facilitarían la proliferación de compañías, cuyo objetivo tuvo una doble vertiente: por un lado, los participantes con capital podían limitar su responsabilidad a la cantidad aportada en calidad de fondo fundacional, con lo cual salvaguardaban el resto de su patrimonio. Por otro lado, con esa forma de inversión buscaban mayor rentabilidad a sus inversiones, lográndolo cuando los beneficios empresariales superaban los tipos de interés. La inmensa mayoría de esas sociedades dispuso de un fondo fundacional superior a los 180.000 reales, con un alto índice de solvencia, aunque tuvieron que sortear un elemento tan antagónico como era asumir unas deudas considerables y un fuerte índice de morosidad. A la fin y a la postre, los resultados finales fueron bastante satisfactorios al lograr una óptima rentabilidad.

148 Escritura suscrita por el clérigo Gregorio López del Aguila y el mercader Juan de Segovia. AHPT. Protocolo 3535, fol. 75, 1667, Nicolás López.

Hispania, LXII/1, núm. 210 (2002) 65-112 
APÉNDICE I. Compañías dedicadas al comercio de artículos sederos (1660-1697)

\begin{tabular}{|c|c|c|c|c|c|}
\hline SOCIO CAPITALISTA & FACTOR & CAPITAL-RLS & ACTIVIDAD & $\begin{array}{l}\text { Plazo- } \\
\text { AÑOS }\end{array}$ & $\begin{array}{c}\text { CONSTITUCIÓN. } \\
\text { AÑo }\end{array}$ \\
\hline Francisco Maganto & Juan de Lodosa & 600.000 & Sedas & 4 & 1674 \\
\hline $\begin{array}{l}\text { Sebastián Magán y } \\
\text { Juan Becerril }\end{array}$ & Bartolomé Martín & 574.173 & “. & 4 & 1673 \\
\hline María de Villarroel & Diego Pinillos & 555.000 & $\begin{array}{c}\text { Sedas- } \\
\text { estameñas }\end{array}$ & 4 & 1660 \\
\hline $\begin{array}{l}\text { Juan Becerril y } \\
\text { Francisco Gómez }\end{array}$ & Bartolomé Martín & 500.000 & Sedas-otros & 3 & 1677 \\
\hline Isabel Aguilera & Francisco Lozano & 472.000 & Sedas & 3 & 1673 \\
\hline María Villarroel & Diego Pinillos & 422.650 & $\begin{array}{c}\text { Sedas- } \\
\text { jerguillas }\end{array}$ & 3 & 1661 \\
\hline Manuela de Rojas & $\begin{array}{l}\text { Francisco Alamo y } \\
\text { Alonso Martín }\end{array}$ & 411.182 & Sedas & 6 & 1661 \\
\hline $\begin{array}{l}\text { Juan Castresana y } \\
\text { Juan Mateo del } \\
\text { Rincón }\end{array}$ & Francisco Lozano & 400.000 & Sedas & 4 & 1674 \\
\hline Catalina Gutiérrez & $\begin{array}{l}\text { Pedro Giménez } \\
\text { Mayorga }\end{array}$ & 380.000 & $\begin{array}{c}\text { Sedas- } \\
\text { estameñas }\end{array}$ & 3 & 1667 \\
\hline $\begin{array}{l}\text { María Valle Sagre- } \\
\text { do y Francisco } \\
\text { Jiménez }\end{array}$ & Juan Bautista & 378.406 & Sedas & 4 & 1697 \\
\hline Isabel Aguilera & Francisco Lozano & 372.000 & Sedas & 4 & 1682 \\
\hline $\begin{array}{l}\text { Alejandro Ruiz de } \\
\text { Guzmán }\end{array}$ & José Romo Tejero & 340.000 & “ & 4 & 1674 \\
\hline $\begin{array}{l}\text { Juan Fernández de } \\
\text { Huerta }\end{array}$ & Diego Dávila & 335.417 & $"$ & 3 & 1675 \\
\hline $\begin{array}{l}\text { Juan Calderón de la } \\
\text { Barca }\end{array}$ & Mateo García & 330.279 & Sedas-otros & 6 & 1675 \\
\hline María de la Fuente & Juan Fernández & 326.000 & Sedas & 6 & 1678 \\
\hline $\begin{array}{l}\text { María de la Fuente } \\
\text { y Diego Dávila }\end{array}$ & Juan Fernández & 321.712 & “ & 4 & 1675 \\
\hline $\begin{array}{l}\text { María Alonso de } \\
\text { Martín }\end{array}$ & $\begin{array}{l}\text { Diego Alonso } \\
\text { Paniagua }\end{array}$ & 318.000 & “ & 3 & 1679 \\
\hline $\begin{array}{l}\text { Francisco Fernán- } \\
\text { dez Salinas }\end{array}$ & Cristóbal García & 313.686 & “ & 3 & 1673 \\
\hline $\begin{array}{l}\text { José y Francisco } \\
\text { Gutiérrez de Oliva- } \\
\text { res }\end{array}$ & $\begin{array}{l}\text { Francisco Martí- } \\
\text { nez }\end{array}$ & 309.294 & “ & 2 & 1668 \\
\hline $\begin{array}{l}\text { María Díaz de } \\
\text { Santos }\end{array}$ & $\begin{array}{l}\text { Blas Gómez Ga- } \\
\text { mero }\end{array}$ & 306.000 & “ & 3 & 1668 \\
\hline $\begin{array}{l}\text { Diego Dávila To- } \\
\text { rres }\end{array}$ & Alonso Ramírez & 306.000 & “ & 4 & 1683 \\
\hline
\end{tabular}




\begin{tabular}{|c|c|c|c|c|c|}
\hline SOCIO CAPITALISTA & FACTOR & CAPITAL-RLS & ACTIVIDAD & $\begin{array}{l}\text { Plazo- } \\
\text { años }\end{array}$ & $\begin{array}{c}\text { CONSTITUCión. } \\
\text { AÑ̃o }\end{array}$ \\
\hline $\begin{array}{l}\text { Juan Fernández de } \\
\text { Huerta }\end{array}$ & Diego Dávila & 304.400 & “ & 2 & 1668 \\
\hline $\begin{array}{l}\text { María Díaz de } \\
\text { Santos }\end{array}$ & $\begin{array}{l}\text { Blas Gómez Ga- } \\
\text { mero }\end{array}$ & 300.000 & " & 3 & 1669 \\
\hline $\begin{array}{l}\text { Francisco Fernán- } \\
\text { dez Salinas }\end{array}$ & Marcos González & 300.000 & “ & 3 & 1665 \\
\hline $\begin{array}{l}\text { Angela y Alejandro } \\
\text { Ruiz }\end{array}$ & Manuel Muñoz & 300.000 & “ & 3 & 1667 \\
\hline $\begin{array}{l}\text { Alejandro Ruiz de } \\
\text { Guzmán }\end{array}$ & $\begin{array}{l}\text { Diego Sotocame- } \\
\text { no }\end{array}$ & 300.000 & “ & 4 & 1668 \\
\hline $\begin{array}{l}\text { Alejandro Ruiz de } \\
\text { Guzmán }\end{array}$ & José Romo & 300.000 & “ & 4 & 1678 \\
\hline $\begin{array}{l}\text { Bernardino de } \\
\text { Beizama }\end{array}$ & \begin{tabular}{|l|} 
Pedro Leonardo \\
Boyra \\
\end{tabular} & 3001000 & Sedas y lanas & 4 & 1679 \\
\hline $\begin{array}{l}\text { Juan de Segovia } \\
\text { Urquizu }\end{array}$ & José Romo Tejero & 300.000 & Sedas & 2 & 1662 \\
\hline $\begin{array}{l}\text { Juan de Segovia } \\
\text { Urquizu }\end{array}$ & $\begin{array}{l}\text { Francisco Bazte- } \\
\text { rrica }\end{array}$ & 300.000 & “ & 4 & 1673 \\
\hline $\begin{array}{l}\text { Alejandro Ruiz de } \\
\text { Guzmán }\end{array}$ & $\begin{array}{l}\text { Francisco Bazte- } \\
\text { rrica }\end{array}$ & 300.000 & “ & 6 & 1679 \\
\hline Juan Becerril & Martín García & 300.000 & " & 3 & 1678 \\
\hline $\begin{array}{l}\text { Francisco de la } \\
\text { Cruz }\end{array}$ & \begin{tabular}{|l|} 
Francisco de \\
Bargas \\
\end{tabular} & 300.000 & · & 4 & 1685 \\
\hline $\begin{array}{l}\text { Jerónima de la } \\
\text { Palma, Fco. Alza- } \\
\text { mora }\end{array}$ & $\begin{array}{l}\text { Antonio y Juan } \\
\text { Montehermoso }\end{array}$ & 300.000 & “ & 3 & 1675 \\
\hline $\begin{array}{l}\text { Bernardino Beyza- } \\
\text { ma }\end{array}$ & $\begin{array}{l}\text { Pedro Leonardo } \\
\text { Boyra } \\
\end{array}$ & 284.970 & “ & 3 & 1685 \\
\hline $\begin{array}{l}\text { Alejandro Ruiz de } \\
\text { Guzmán }\end{array}$ & José Romo Tejero & 284.000 & “ & 4 & 1674 \\
\hline $\begin{array}{l}\text { Cristóbal de Balma- } \\
\text { seda }\end{array}$ & $\begin{array}{l}\text { Martín García del } \\
\text { Moral }\end{array}$ & 280.155 & “ & 3 & 1671 \\
\hline $\begin{array}{l}\text { Juan Calderón de la } \\
\text { Barca }\end{array}$ & Gaspar Ferrer & 280.000 & Seda hilada & 1 & 1662 \\
\hline Francisco Estrada & Vicente de Sales & 260.000 & “ & 1 & 1663 \\
\hline José Vázquez & \begin{tabular}{|l} 
Fco. Fdez de \\
Salinas \\
\end{tabular} & 252.000 & Sedas & 4 & 1652 \\
\hline $\begin{array}{l}\text { Juan Mateo del } \\
\text { Rincón }\end{array}$ & $\begin{array}{l}\text { Juan de Castresa- } \\
\text { na y Mateo García }\end{array}$ & 251.941 & “ & 4 & 1672 \\
\hline Marcela de Navas & Agustín Amador & 251.000 & " & 2 & 1676 \\
\hline $\begin{array}{l}\text { Francisco Fdez de } \\
\text { Huerta }\end{array}$ & Cristóbal Báez & 250.923 & “ & 4 & 1681 \\
\hline
\end{tabular}

